HC.P/T2898-01/5

\title{
OTEC Thermal Resource Report for Western Coast Mexico
}

May 1979

Prepared for U.S. Department of Energy Assistant Secretary for Energy Technology Division of Central Solar Technology

Under Contract No. ET-78-C-01-2898 


\section{DISCLAIMER}

This report was prepared as an account of work sponsored by an agency of the United States Government. Neither the United States Government nor any agency Thereof, nor any of their employees, makes any warranty, express or implied, or assumes any legal liability or responsibility for the accuracy, completeness, or usefulness of any information, apparatus, product, or process disclosed, or represents that its use would not infringe privately owned rights. Reference herein to any specific commercial product, process, or service by trade name, trademark, manufacturer, or otherwise does not necessarily constitute or imply its endorsement, recommendation, or favoring by the United States Government or any agency thereof. The views and opinions of authors expressed herein do not necessarily state or reflect those of the United States Government or any agency thereof. 


\section{DISCLAIMER}

Portions of this document may be illegible in electronic image products. Images are produced from the best available original document. 
Available from:

National Technica1 Information Service (NTIS)

U.S. Department of Commerce

5285 Port Royal Road

Springfield, Virginia 22161

Price: Printed copy: $\$ 4.50$

Microfiche: $\quad \$ 3.00$ 


\section{OTEC Thermal Resource Report for Western Coast Mexico}

May 1979

Prepared for

U.S. Department of Energy

Assistant Secretary for Energy Technology

Division of Central Solar Technology

Washington, D.C. 20585

Prepared by

William Alan Wolff

Ocean Data Systems, Inc.

Monterey, California 93940

Under Contract No. ET-78-C-01-2898

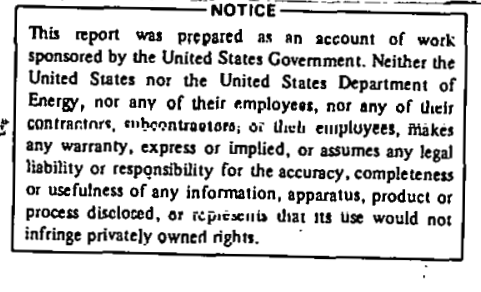




\section{NOTICE}

This report was prepared as an account of work sponsored by the United States Government. Neither the United States nor the United States Department of Energy, nor any of their employees, makes any warranty, express or implied, or assumes any legal liability or responsibility for the accuracy, completeness, or usefulness of any Infunitiotion, opparatus, nroduct, or process disclosed, or represents that its use would not infringe privately owned rights. Reference

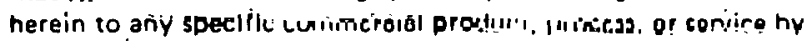
trade name, mark, manufacturer, or otherwise, does not necessarily constitute or imply its endorsement, recommendation, or favoring by the United States Government or any agency thereof. The views and opinions of authors expressed herein do not necessarily state or reflect those of the United States Government or any agency thereof. 
TABLE OF CONTENTS

Section

$\underline{\text { Page }}$

INTRODUCTION

ii

I. EXECUTIVE SUMMARY

In

II.

BATHYMETRY

II 1

III.

THERMAL RESOURCE

III-1

IV.

MIXED LAYER DEPTH

IV -1

V. WEATHER CONDITIONS

$\mathrm{V}-1$

VI. SEA AND SWELL CHARACTERISTICS

VI -1

VII.

CURRENTS .

VIII

REFERENCES

$R-1$ 
SUMMARY OF 'SITE PARAMETERS

\begin{tabular}{|c|c|c|c|c|c|c|}
\hline site & $\begin{array}{l}\text { Monthly Mean } \\
\text { Temperature }\left({ }^{\circ} \mathrm{C}\right) \\
\text { Surface Range }\end{array}$ & $\begin{array}{c}\text { Monthly Mean } \\
\text { Temperature }\left({ }^{\circ} \mathrm{C}\right) \\
\text { I000M }\end{array}$ & $\begin{array}{c}\text { Annual } \\
\text { Mean } \\
\Delta \mathrm{T}\left({ }^{\circ} \mathrm{C}\right) \quad 500 \mathrm{M} \\
\end{array}$ & $\begin{array}{c}\text { Annual } \\
\text { Mean } \\
\Delta \mathrm{T}\left({ }^{\circ} \mathrm{C}\right) \quad 1000 \mathrm{M} \\
\end{array}$ & $\begin{array}{c}\text { Coldest Monthly } \\
\text { Mean } \Delta \mathrm{T}\left({ }^{\circ} \mathrm{C}\right) \\
500 \mathrm{M} \\
\end{array}$ & $\begin{array}{c}\text { Coldest Monthly } \\
\text { Mean } \Delta \mathrm{T}\left({ }^{\circ} \mathrm{C}\right) \\
1000 \mathrm{M} \\
\end{array}$ \\
\hline Sri Lanka & $27.5-28.6$ & $6.5-6.7$ & $1 B .0$ & 21.3 & 17.5 & 20.8 \\
\hline Mombasa $\mathrm{N}$ & $25.4-28.7$ & $7.2-7.5$ & 17.0 & 19.5 & 15.6 & 18.2 \\
\hline Mombasa $S$ & $25.5-28.4$ & $6.3-7.0$ & 13.0 & 20.2 & 15.9 & 18.5 \\
\hline Jakarta & $27.2-29.0$ & $5.1-5.6$ & 19.1 & 22.8 & 17.9 & 21.9 \\
\hline Dampier Land & $25.6-28.2$ & $4.9-5.0$ & 19.1 & 22.6 & 17.4 & 20.7 \\
\hline Manila & $27.1-29.5$ & $4.4-4.6$ & 20.0 & 24.0 & 18.6 & 22.6 \\
\hline Guam & $27.7-29.2$ & $4.3-4.4$ & 21.1 & 24.1 & 20.4 & 23.4 \\
\hline Off Mexico & $22.5-28.0$ & $4.4-4.5$ & 17.6 & 20.9 & 14.9 & 18.0 \\
\hline $\begin{array}{l}\text { Plant ship } \\
\text { Pacific }\end{array}$ & $27.1-28.5$ & $4.6-4.8$ & 19.4 & 22.8 & $18 . i$ & 21.7 \\
\hline Ivory Coast & $24.3-28.1$ & 4.5 & 19.2 & 22.1 & 16.8 & 19.7 \\
\hline $\begin{array}{l}\text { Plant Ship } \\
\text { Caribbean }\end{array}$ & $26.4-28.4$ & $5.0-5.3$ & 18.1 & 22.4 & 17.2 & 21.3 \\
\hline
\end{tabular}




\section{SUMMARY OF`SITE PARAMETERS}

\begin{tabular}{|c|c|c|c|c|c|c|}
\hline SITE & $\begin{array}{l}\text { RANGE DISTANCE } \\
\text { (IN KILOMETERS) } \\
\text { TO SHORE FROM } \\
1000 \text { NETERS } \\
\end{array}$ & $\begin{array}{l}\text { MONTHLY MEAN } \\
\text { MIXED LAYER } \\
\text { DEPTH METERS }\end{array}$ & $\begin{array}{l}\text { MONTHLY MEAN } \\
\text { SURFACE CURRENTS } \\
\text { (CM/SEC) }\end{array}$ & & $\begin{array}{l}\text { SEA STATE MA } \\
8 \text { OF TIME }>3 \\
\text { METERS }\end{array}$ & $\begin{array}{l}\text { NUMBER TROPICAL } \\
\text { CYCLONES PER } \\
\text { YEAR }\end{array}$ \\
\hline SRI LANKA & $22-55$ & $30-80$ & $25-62$ & & 3 & $0.2-1.2$ \\
\hline MOMBASA & $33-130$ & $30-90$ & $30-62$ & & 2 & $0.0-0.1$ \\
\hline JARARTA & $18-60$ & $55-80$ & $25-52$ & & 2 & $0.0-0.1$ \\
\hline DAMPIER LAND & $265-417$ & $30-80$ & $25-47$ & & 4 & $0.4-1.2$ \\
\hline MANILA & $6-82$ & $20-80$ & $30-52$ & & 5 & $4.0-6.0$ \\
\hline GUAM & $7-18$ & $60-120$ & $30-47$ & & 5 & $2.0-3.0$ \\
\hline OFF MEXICC & $5-104$ & $10-30$ & $25-31$ & & 2 & $0.6-4.0$ \\
\hline $\begin{array}{l}\text { PLANT SHIP } \\
\text { PACIFIC }\end{array}$ & - & $0-30$ & $30-52$ & & 2 & $0.0-2.0$ \\
\hline IVORY COAST & $33-52$ & $0-30$ & $25-31$ & & 2 & $0.0-0.1$ \\
\hline $\begin{array}{l}\text { PLANT SHIF } \\
\text { CARIBBEAN }\end{array}$ & - & $40-110$ & $30-62$ & & 3 & $0.6-1.2$ \\
\hline
\end{tabular}




\section{EXECUTIVE SUMMARY}

The site chosen for study off the western coast of Mexico between $20-23^{\circ}$ North latitude, 105-110 West longitude has a temperature difference resource which is more than adequate for potential OTEC use. The annual mean $\triangle \mathrm{T}$ to 1000 meters is $20.9^{\circ} \mathrm{C}$. An annual mean $\Delta \mathrm{T}$ of $20.0^{\circ} \mathrm{C}$ is available at 800 meters. The monthly mean $\Delta \mathrm{T}$ for the coldest month 'of the year is $17.2^{\circ} \mathrm{C}$; at 800 meters while there is some variation in the monthly mean temperature difference, even the coldest month is adequate.

The mixed layer depth is very shallow throughout the entire year. Storms are a problem for this area between May and November. Low sea and swell predominate throughout the year. The surface currents are generally weak to moderate with some variation in direction during the year. The continental shelf is fairly wide for most of the region making the distance to shore from depths of 1000 meters somewhat large. There is one bay from which deep water can be reached within 5 kilometers. 
One of the basic environmental considerations in site selection for an Ocean Thermal Energy Conversion (OTEC) power plant is the availability of an adequate temperature difference resource. OTEC plants are designed to convert the potential energy in the temperature difference between the warm ocean surface water and the cold water existing at deeper depths into electricity. The turbines which produce the electricity must run on temperature differentials which are extremely small by the standards of conventional energy plants. Therefore, a definition of the most probable temperature structure for a site is most important.

In order to define temperature structures for OTEC areas of interest, Ocean Data Systems, Inc. (ODSI) has developed computer data files of all unclassified soundings available. The primary sources for the data were NOAA's National Oceanographic Data Center, and the U.S. NavY's Fleet Numerical Weather Central. The files were updated in September 1978. Included in the data base were mechanical bathythermographs (MBT), expendable bathythermographs (XBT), salinity temperature depth syctcms (ETD), and Nansen casts.

Under U.S. Department of Energy, Division of Solar Energy Contract No. EY-78-C-2989, ODSI has analyzed the monthly temperature structure for ten different geographical areas. The ten sites selected for study by the Department of Energy are: 
Latitude Longitude

Bottom Mounted or

Shore Plants:

Dampier Land

$13-18^{\circ} \mathrm{S}$

$118-121^{\circ} \mathrm{E}$

Manila

$14-16^{\circ} \mathrm{N} \quad 118-120^{\circ} \mathrm{E}$

Guam

$12-15^{\circ} \mathrm{N}$

$142-146^{\circ} \mathrm{E}$

Ivory Coast

$3-6^{\circ} \mathrm{N}$

$3-8^{\circ} \mathrm{W}$

Jakarta

$6-9^{\circ} \mathrm{S}$

$104-109^{\circ} \mathrm{E}$

Mexico

$20-23^{\circ} \mathrm{N}$

$105-110^{\circ} \mathrm{W}$.

Sri Lanka

$$
5-10^{\circ} \mathrm{N}
$$

$78-83^{\circ} \mathrm{E}$

Mombasa

$5^{\circ} \mathrm{S}-3^{\circ} \mathrm{N}$

$40-45^{\circ} \mathrm{E}$

Ship Plants: No. 1

$5-10^{\circ} \mathrm{N} \quad 90-95^{\circ} \mathrm{W}$

No. 2

$13-15^{\circ} \mathrm{N}$

$75-80{ }^{\circ} \mathrm{W}$

The location of these sites is shown on the following map; a separate report was produced for each site.

For each area, the most probable temperature structures were determined. When the most probable'temperature soundings were plotted, some month to month variability was present which was caused by the non-uniform data sample rather than by real changes in the ocean. These short-period time variations were removed by a filtering process described by Wolff, et al (1977), [44]. Availability of cold and warm water was examined at each site. In addition to warm and cold water availability, there are other requirements for the continuous operation of an OTEC plant. An adequate temperature differential $(\Delta \mathrm{T})$ is the primary need. $A \Delta T$ greater than $16.7^{\circ} \mathrm{C}\left(30^{\circ} \mathrm{F}\right)$ for the coldest month of the year would enable year round operation. The annual mean $\Delta T$ for 


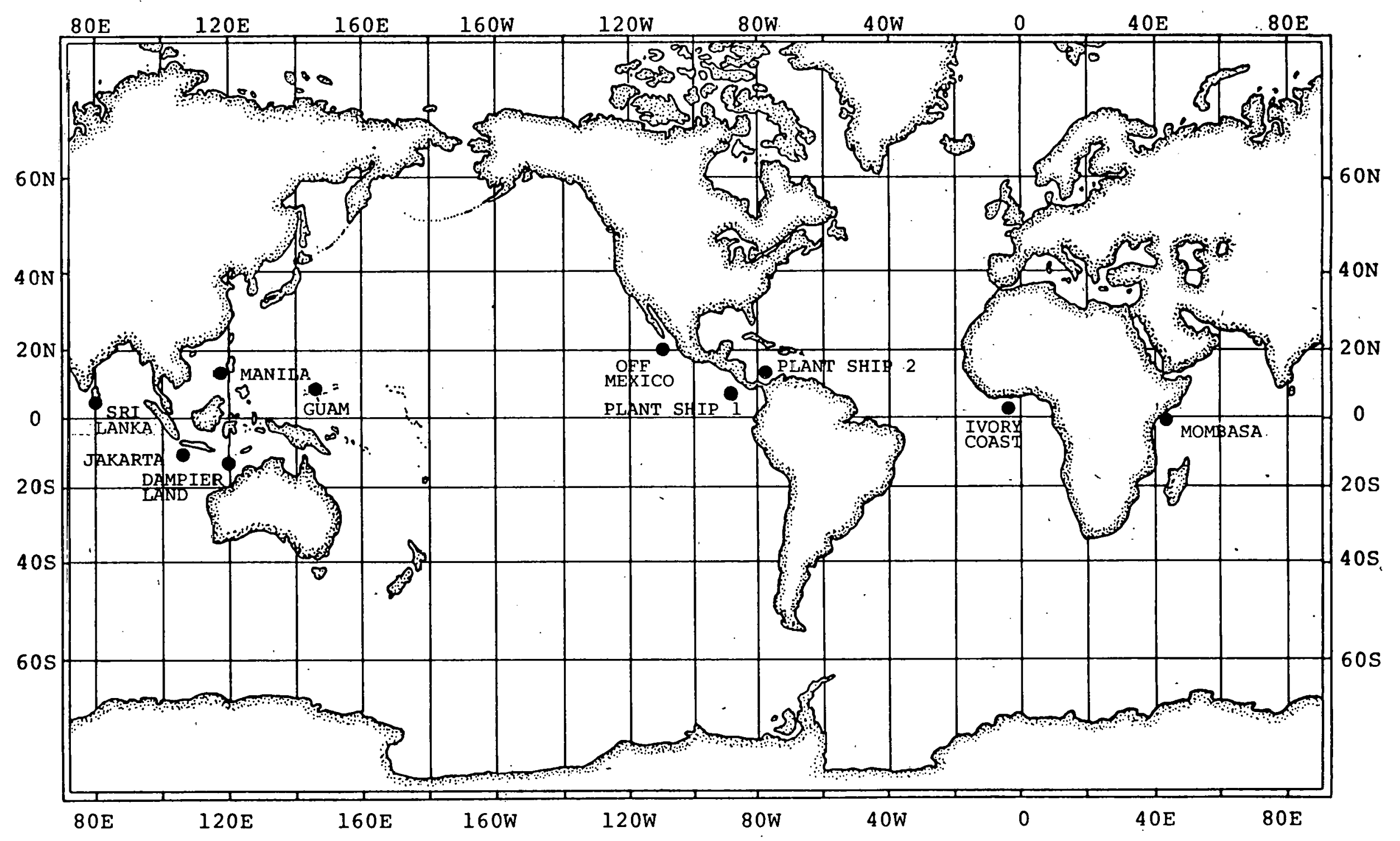

LOCATION OF THE TEN SELECTED SITES 
a site should equal or exceed $20^{\circ} \mathrm{C}\left(36^{\circ} \mathrm{F}\right)$. Besides the thermal resource, there are other operational requirements. Bottom depth should be less than 1500 meters for mooring. Minimum distances offshore, to 1000-meter depth is another important consideration for shore plants. Currents should be sufficient to guarantee good cold/warm water sources and to provide for dispersion of modified water. Desirable sites also have light winds, minimum sea and swell, and the lack of severe storms. These parameters have been examined for each site. The following tables sumnarize some nf the key site parameters for each location. 
II.. BATHYMETRY

. Figure II-l shows the general location of the site selected off Mexico. Figure II-2 provides a rough bathymetry of the area under consideration to depths of 1500 meters. The source of bathymetry is the U.S. Naval Bathymetric Atlas of the Northeastern Pacific Ocean (1971), [40]. The continental shelf is fairly wide for most of this region, making distances to shore fairly large from the 500 and 1000 meter depth. This is especially true for the area off the coast between $21-23^{\circ} \mathrm{N}$. At $20^{\circ} 30^{\prime} \mathrm{N}$ in Banderas Bay there is the Banderas Canyon that provides deep water within 4-5 kilometers. Distance to 1000 meters are generally less between $16^{\circ} \mathrm{N}-20^{\circ} \mathrm{N}$ than $20^{\circ}-23^{\circ} \mathrm{N}$ however. Table II-l summarizes. extreme distances from shore to specified depths.

TABLE II-1: DISTANCES TO SELECTED DEPTHS FOR LOCATIONS OFF MEXICO. From

- U.S. Naval Oceanographic Office, (1971), [40].

\begin{tabular}{|ccc|}
\hline $\begin{array}{c}\text { DEPTH } \\
\text { (Meters) }\end{array}$ & $\begin{array}{c}\text { CLOSEST DISTANCE } \\
\text { (Kilometers) }\end{array}$ & $\begin{array}{c}\text { FARTHEST DISTANCE } \\
\text { (Kilometers) }\end{array}$ \\
\hline 100 & 1.8 & 69 \\
500 & 3.7 & 100 \\
1000 & 5.6 & 104 \\
1500 & 11.1 & 141 \\
\hline
\end{tabular}




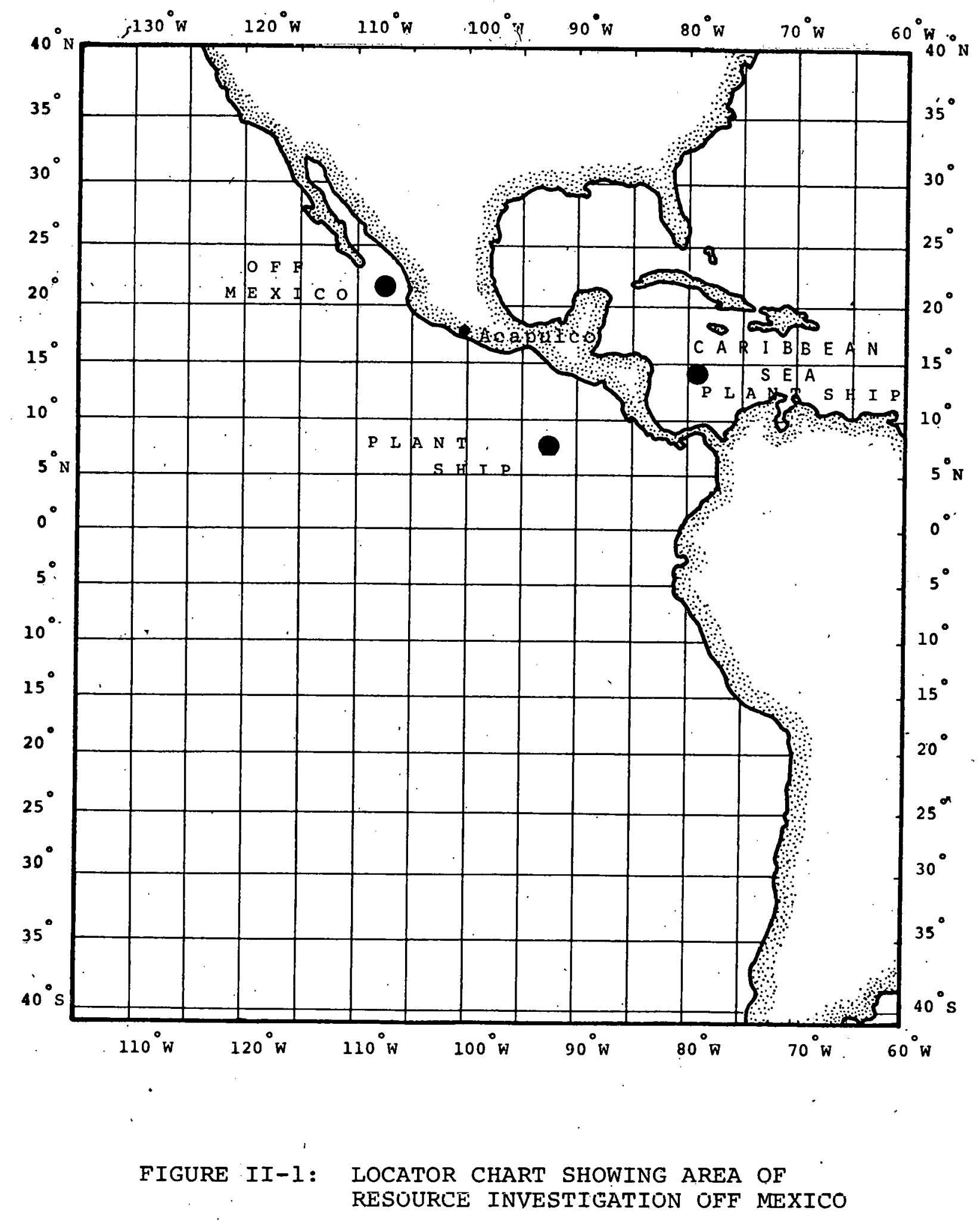




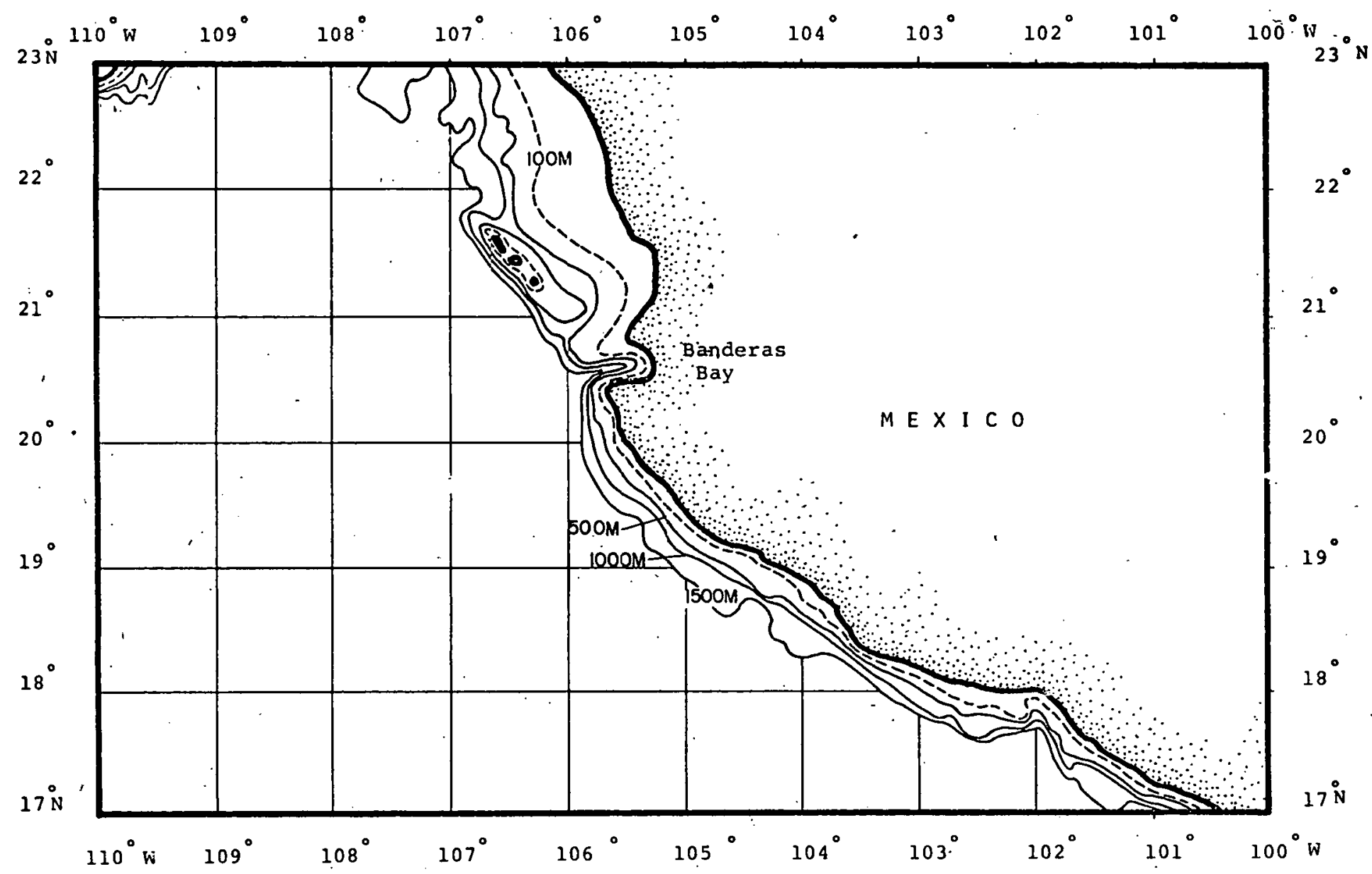

FIGURE II-2: CHART SHOWING ROUGH BATHYMETRY OFF MEXICO TO DEPTHS OF 1500 METERS. From U.S. Naval Oceanographic office, (1971), [40]. 
III. THERMAL RESOURCE

The main sources for the temperature data contained in this report were NOAA's National Oceanographic Data Center, and the U.S. Navy's Fleet Numerical Weather Central, although soundings from other sources were added when available. For the site examined off the western coast of Mexico between 20-23 north latitude and $105-110^{\circ}$ west longitude there was data for: each month of the year at every depth in 50 meter increments from the surface to 1000 meters. Below 1000 meters there was no data for some months and some depths, and what data existed was sparse. When the available data was plotted some month-to-month variability was present which was caused by the sparse and non-uniform data sample rather than by real variations in the ocean. These shortperiod time variations were removed by a filtering process described by wolff, et al (1977), [ㄴ4].

Table III-l provides the monthly most probable temperature $\left({ }^{\circ} \mathrm{C}\right)$ profile as a function of depth for this site. The annual mean temperatures for each depth were computed by averaging the monthly most probable temperature figures. Table III-2 shows the same data tabulated in terms of $\Delta T$, the surface temperature minus the temperature at depth differential $\left({ }^{\circ} \mathrm{C}\right)$. The annual mean $\Delta \mathrm{T}$ was computed by taking the differential of the annual mean temperature at depth from Table III-I. The thermal resource for the site selected off the western coast of Mexico is a good one with 
an annual mean $\Delta \mathrm{T}$ of $20.0^{\circ} \mathrm{C}$ available at 800 meters. The monthly $\Delta$ Ts show a fairly wide range however. The variation is due to seasonal variation of the surface temperature, and not to any appreciable variation at depth. Indeed from 600 meters and deeper the monthly mean temperatures are extremely consistent.

Figure III-l provides a plot of monthly $\Delta \mathrm{T}$ contours for the off Mexico site: These contours show the seasonal variation. Still the thermal resource is a good one. 
TABLE III-1: MONTHLY MOST PROBABLE TEMPERATURE ( $\left.{ }^{\circ} \mathrm{C}\right)$ PROFILE

OFF MEXICO $20-23^{\circ} \mathrm{N} / 105-110^{\circ} \mathrm{W}$

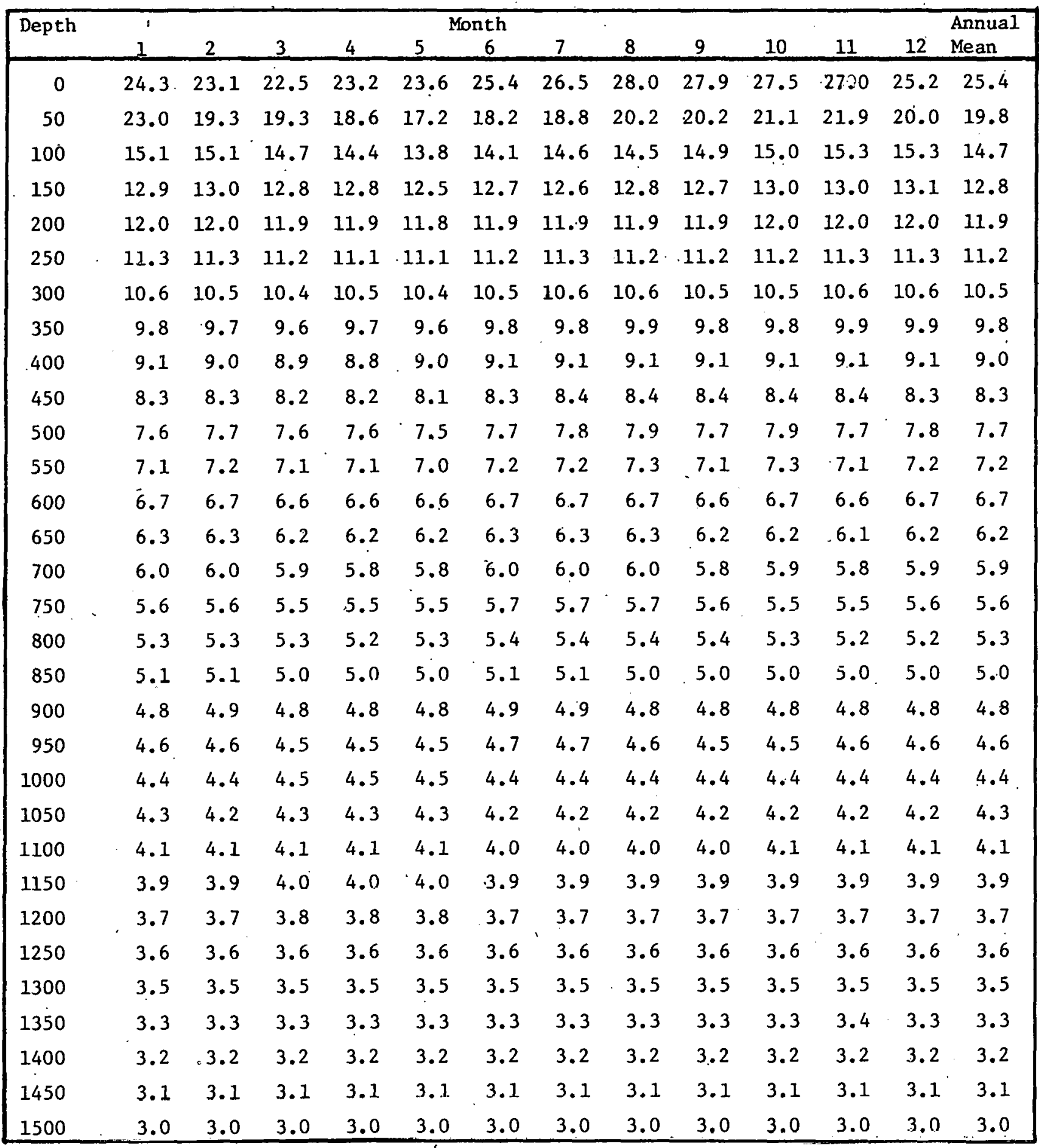


TABLE III-2: SURFACE TEMPERATURE - TEMPERATURE AT DEPTH

DIFFERENTIAL $\left({ }^{\circ} \mathrm{C}\right)$ BY MONTHS OFF MEXICO $20-23^{\circ} \mathrm{N} / 105^{\circ}-110^{\circ} \mathrm{W}$

\begin{tabular}{|c|c|c|c|c|c|c|c|c|c|c|c|c|c|}
\hline \multirow[t]{2}{*}{ Depth } & \multicolumn{12}{|c|}{ Month } & \multirow{2}{*}{$\begin{array}{c}\text { Annual } \\
\text { Mean }\end{array}$} \\
\hline & 1 & 2 & 3 & 4 & 5 & 6 & 7 & 8 & 9 & 10 & 11 & 12 & \\
\hline 50 & 1.3 & 3.8 & 3.2 & 4.6 & 6.4 & 7.2 & 7.7 & 7.8 & 7.7 & 6.4 & 5.1 & 5.2 & 5.5 \\
\hline 100 & 9.2 & 8.0 & 7.8 & 8.8 & 9.8 & 11.3 & 11.9 & 13.5 & 13.0 & 12.5 & 11.7 & 9.9 & 10.6 \\
\hline 150 & 11.4 & 10.1 & 9.7 & 10.4 & 11.1 & 12.7 & 13.9 & 15.2 & 15.2 & 14.5 & 14.0 & 12.1 & 12.5 \\
\hline 200 & 12.3 & 11.1 & 10.6 & 11.3 & 11.8 & 13.5 & 14.6 & 16.1 & 16.0 & 15.5 & 15.0 & 13.2 & 13.4 \\
\hline 250 & 13.0 & 11.8 & 11.3 & 12.1 & 12.5 & 14.2 & 15.2 & 16.8 & 16.7 & 16.3 & 15.7 & 13.9 & 14.1 \\
\hline 300 & 13.7 & 12.6 & 12.1 & 12.7 & 13.2 & 14.9 & 15.9 & 17.4 & 17.4 & 17.0 & 16.4 & 14.6 & 14.8 \\
\hline 350 & 14.5 & 13.4 & 12.9 & 13.5 & 14.0 & 15.6 & 16.7 & 18.1 & 18.1 & 17.7 & 17.1 & 15.3 & 15.6 \\
\hline 400 & 15.2 & 14.1 & 13.6 & 14.4 & 14.6 & 16.3 & 17.4 & 18.9 & 18.8 & 18.4 & 17.9 & 16.1 & 16.3 \\
\hline 450 & 16.0 & 14.8 & 14.3 & 15.0 & 15.5 & 17.1 & 18.1 & 19.6 & 19.5 & 19.1 & 18.6 & 16.9 & 15.8 \\
\hline 500 & 16.7 & 15.4 & 14.9 & 15.6 & 16.1 & 17.7 & 18.7 & 20.1 & 20.2 & 19.6 & 19.3 & 17.4 & 17.6 \\
\hline 550 & 17.2 & 15.9 & 15.4 & 16.1 & 16.6 & 18.2 & 19.3 & 20.7 & 20.8 & 20.2 & 19.9 & 18.0 & 18.2 \\
\hline 600 & 17.6 & 16.4 & 15.9 & 16.6 & 17.0 & 18.7 & 19.8 & 21.3 & 21.3 & 20.8 & 20.4 & 18.5 & 18.7 \\
\hline 650 & 18.0 & 16.8 & 16.3 & 17.0 & 17.4 & 19.1 & 20.2 & 21.7 & 21.7 & 21.3 & 20.9 & 19.0 & 19.1 \\
\hline 700 & 18.3 & 17.1 & 16.6 & 17.4 & 17.8 & 19.4 & 20.5 & 22.0 & 22.1 & 21.6 & 21.2 & 19.3 & 19.4 \\
\hline 750 & 18.7 & 17.5 & 17.0 & 17.7 & 18.1 & 19.7 & 20.8 & 22.3 & 22.3 & 22.0 & 21.5 & 19.6 & 19.8 \\
\hline 800 & 19.0 & 17.8 & 17.2 & 18.0 & 18.3 & 20.0 & 21.1 & 22.6 & 22.5 & 22.2 & 21.8 & 20.0 & 20.0 \\
\hline 850 & 19.2 & 18.0 & 17.5 & 18.2 & 18.6 & 20.3 & 21.4 & 23.0 & 22.9 & 22.5 & 22.0 & 20.2 & 20.3 \\
\hline 900 & 19.5 & 18.2 & 17.7 & 18.4 & 18.8 & 20.5 & 21.6 & 23.2 & 23.1 & 22.7 & 22.2 & 20.4 & 20.5 \\
\hline 950 & 19.7 & 18.5 & 18.0 & 18.7 & 19.1 & 20.7 & 21.8 & 23.4 & 23.4 & 23.0 & 22.4 & 20.6 & 20.8 \\
\hline 1000 & 19.9 & 18.7 & 18.0 & 18.7 & 19.1 & 21.0 & 22.1 & 23.6 & 23.5 & 23.1 & 22.6 & 20.8 & 20.9 \\
\hline 1050 & 20.0 & 18.9 & 18.2 & 18.9 & 19.3 & 21.2 & 22.3 & 23.8 & 23.7 & 23.3 & 22.8 & 21.0 & 21.1 \\
\hline 1100 & 20.2 & 19.0 & 18.4 & 19.1 & 19.5 & 21.4 & 22.5 & $24 . U$ & 23.9 & 23.4 & 22.9 & 21.1 & 21.3 \\
\hline 1150 & 20.4 & 19.2 & 18.5 & 19.2 & 19.6 & 21.5 & 22.6 & 24.1 & 24.0 & 23.6 & 23.1 & 21.3 & 21.4 \\
\hline 1200 & 20.6 & 19.4 & 18.7 & 19.4 & 19.8 & 21.7 & 22.8 & 24.3 & 24.2 & 23.8 & 23.3 & 2.15 & 21.6 \\
\hline 1250 & 20.7 & 19.5 & 18.9 & 19.6 & 20.0 & 21.8 & 22.9 & 24.4 & 24.3 & 23.9 & 23.4 & 21.6 & 21.8 \\
\hline 1300 & 20.8 & 19.6 & 19.0 & 19.7 & 20.1 & 21.9 & 23.0 & 24.5 & 24.4 & 24.0 & 23.5 & 2.17 & 21.9 \\
\hline 1350 & 21.0 & 19.8 & 19.2 & 19.9 & 20.3 & 22.1 & 23.2 & 24.7 & 24.6 & 24.2 & 23.6 & 21.9 & 22.0 \\
\hline 1400 & 21.1 & 13.9 & 19.3 & 20.0 & 20.4 & 22.2 & 23.3 & 24.8 & 24.7 & 24.3 & 23.8 & 22.0 & 22.2 \\
\hline 1450 & 21.2 & 20.0 & 19.4 & 20.1 & 20.5 & 22.3 & 23.4 & 24.9 & 24.8 & 24.4 & 23.9 & 22.1 & 22.3 \\
\hline 1500 & 21.3 & 20.1 & 19.5 & 20.2 & 20.6 & 22.4 & 23.5 & 25.0 & 24.9 & 24.5 & 24.0 & 22.2 & 22.4 \\
\hline
\end{tabular}




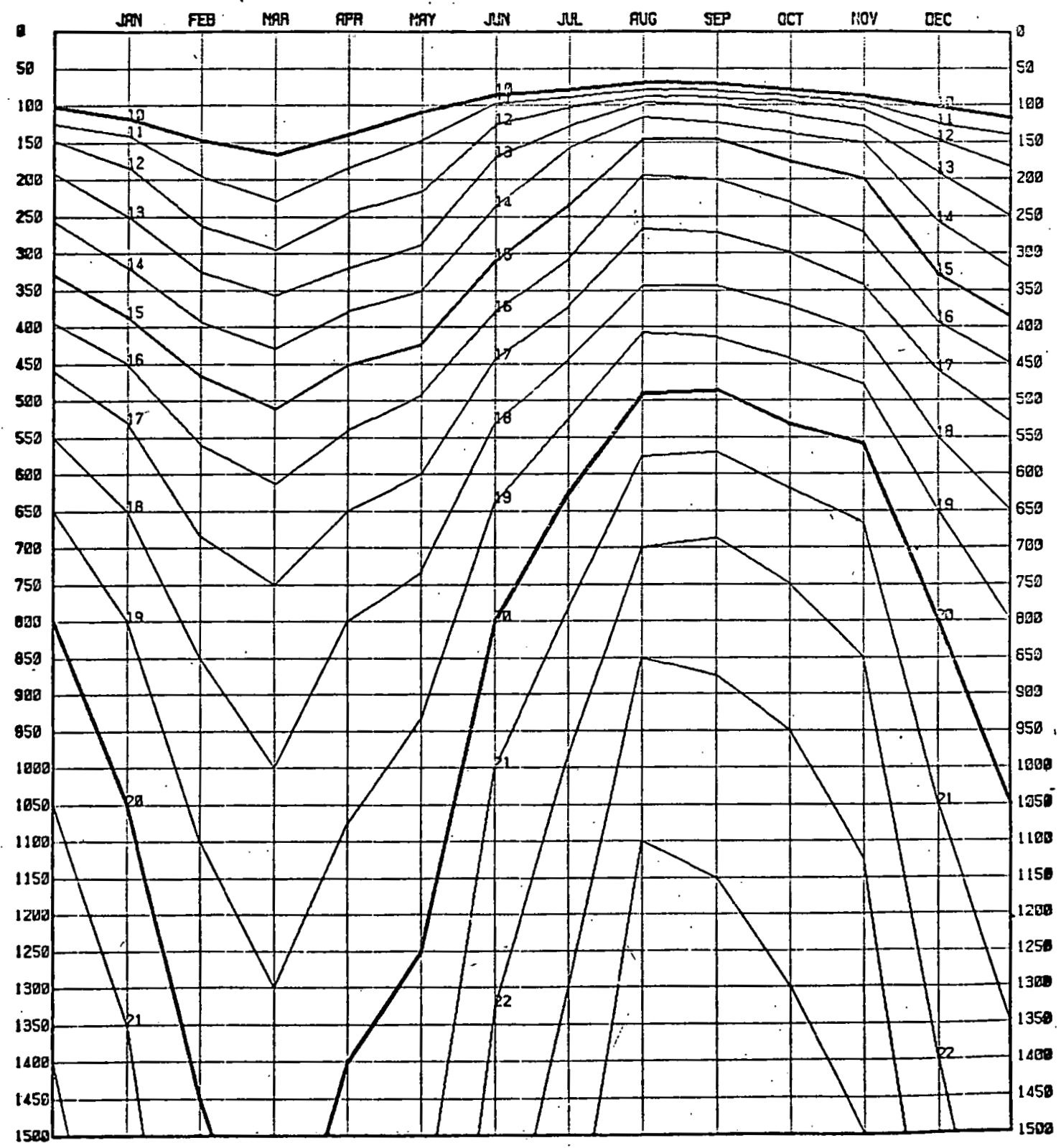

FIGURE III-1: CHART SHOWING MONTHLY $\triangle T$ T CONTOURS $\left({ }^{\circ} \mathrm{C}\right)$ AT A DEPTH RESOLUTION OF 50 METERS FOR THE OFF MEXICO SITE $(20-23 \mathrm{~N} / 105-110 \mathrm{~W})$ 
IV. MIXED LAYER DEPTH

The upper mixed layer depth, MLD, was defined for OTEC purposes to be the depth at which the temperature is first colder than the surface temperature by. $1^{\circ}$ Centigrade. An ever-present mixed layer depth is favorable for OTEC operation. Ideally the MLD is deep enough to assure an intake of uniformly warm water. Also the mixed layer is ideally not so deep that there are problems of recirculation of mixed. exhaust water.

The mixed layer depth of this site off the western coast of Mexico is too shaliow to be ideal for OTEC purposes. Weak and variable currents and winds are the main causes of the shallow MLD throughout the entire year. The Eastropac Atlas, (1971), [32] was consulted for preliminary mixed. layer depths. ODSI's OTEC data file was then analyzed. The monthly mixed layer depths. in meters for this area are shown in Table IV-I.

TABLE IV-1: TYPICAL MIXED LAYER DEPTHS (METERS) OFF MEXICO ..

$\begin{array}{llllll}\frac{\text { JAN }}{30} & \frac{\text { FEB }}{30} & \frac{\text { MAR }}{20}: \frac{\text { APR }}{20}: \frac{\text { MAY }}{20}: \frac{\text { JUN }}{10} . \\ \frac{\text { JUL }}{20} & \frac{\text { AUG }}{20} & \frac{\text { SEP }}{10} & \frac{\text { OCT }}{30} & \frac{\text { NOV }}{30} & \frac{\text { DEC }}{30}\end{array}$


V. . WINDS AND STORMS

High winds and storms are a definite problem for the off Mexico site. Figure $\mathrm{V}-1$ and $\mathrm{V}-2$ are adopted from H.C. Crutcher and R.G. Quayle (1974), [ 7]. Figure V-I shows the preferred annual storm tracks for this site. Figure V-2 provides the average number of tropical cyclones per $5^{\circ}$ square per year. These figures demonstrate that storms will be a problem for this site. The main season is from June through October although storms can also occur in May and November. The number of storms to be expected over a period of ten years per month is:

JAN FEB MAR APR MAY JUN JUL AUG SEP OCT NOV DEC

$\begin{array}{lllllllllllll}\text { Tropical } & 0 & 0 & 0 & 0 & 1 & 3 & 3 & 9 & 7 & 4 & 1 & 0 \\ \text { Storms } & & & & \end{array}$

These figures are derived from records over 106 years. A site farther south along Mexico would provide a better thermal resource, but be subject to even more storms.

Hurricanes will cause winds which may sustain speeds of 30 to 50 meters per seond. Mountainous waves will be produced. Gentry (1970), [18] states that occasional waves of over 20 meters have been reported, and that numerous.reporte of waves 10-15 meters exist. Currents will be formed by hurricanes. Johnson and Denwick indicate that hurricanes can cause a temperature anomaly of $-3^{\circ} \mathrm{C}$ for a period of four days. While this result was measured in the Gulf of Mexico, it is indicative of the effects of hurricanes on the thermal resource anywhere in the tropics. 
Tables V-1 through V-4 with data from the U.S. Naval Weather Service provide information on the winds for each of the ten sites examined.

Figures V-3 through, V-6 from Wolff and Hubert (1976), [43] summarize storm and hurricane statistics by seasons for the area. 


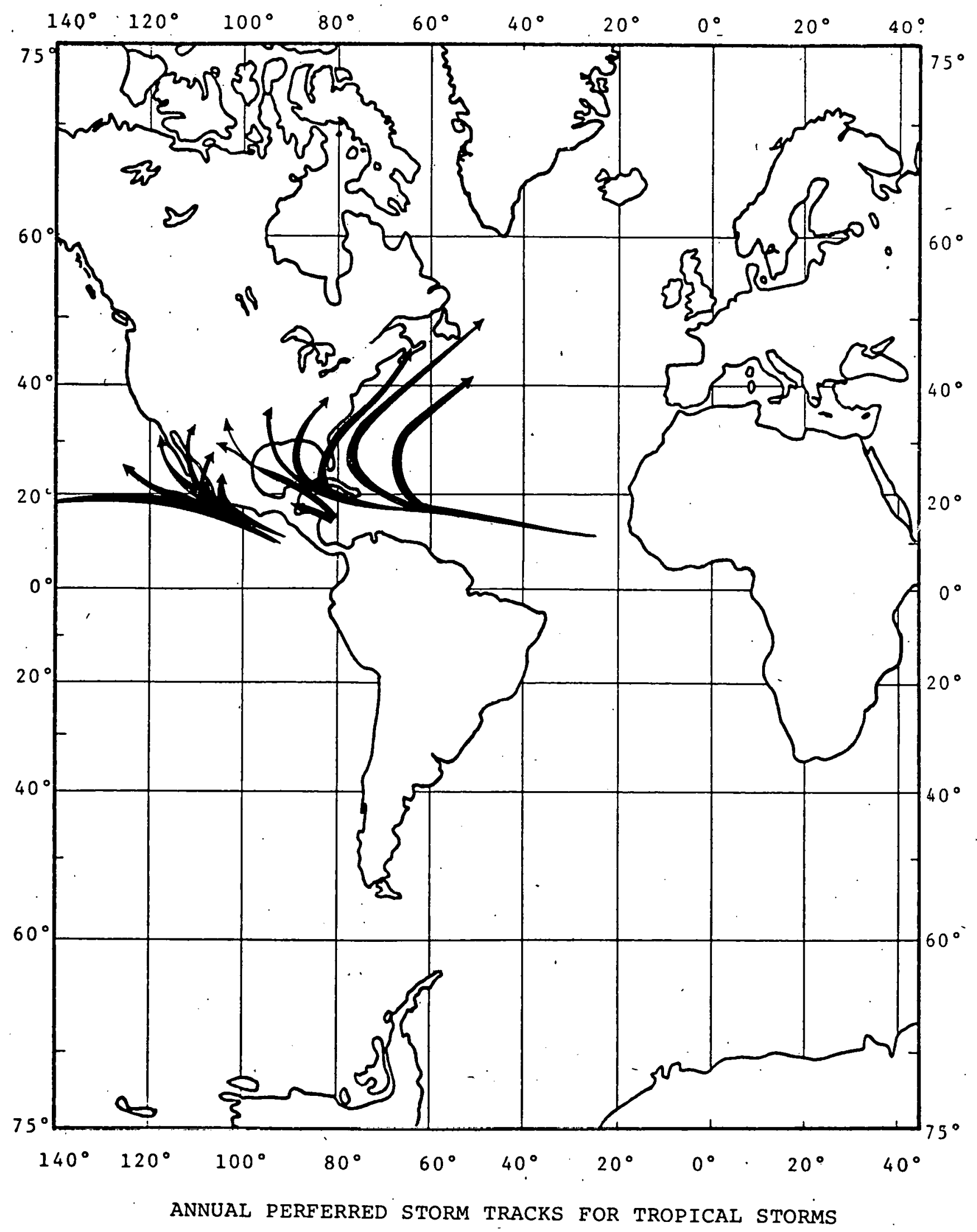

PIGURE V-I

$v-3$ 


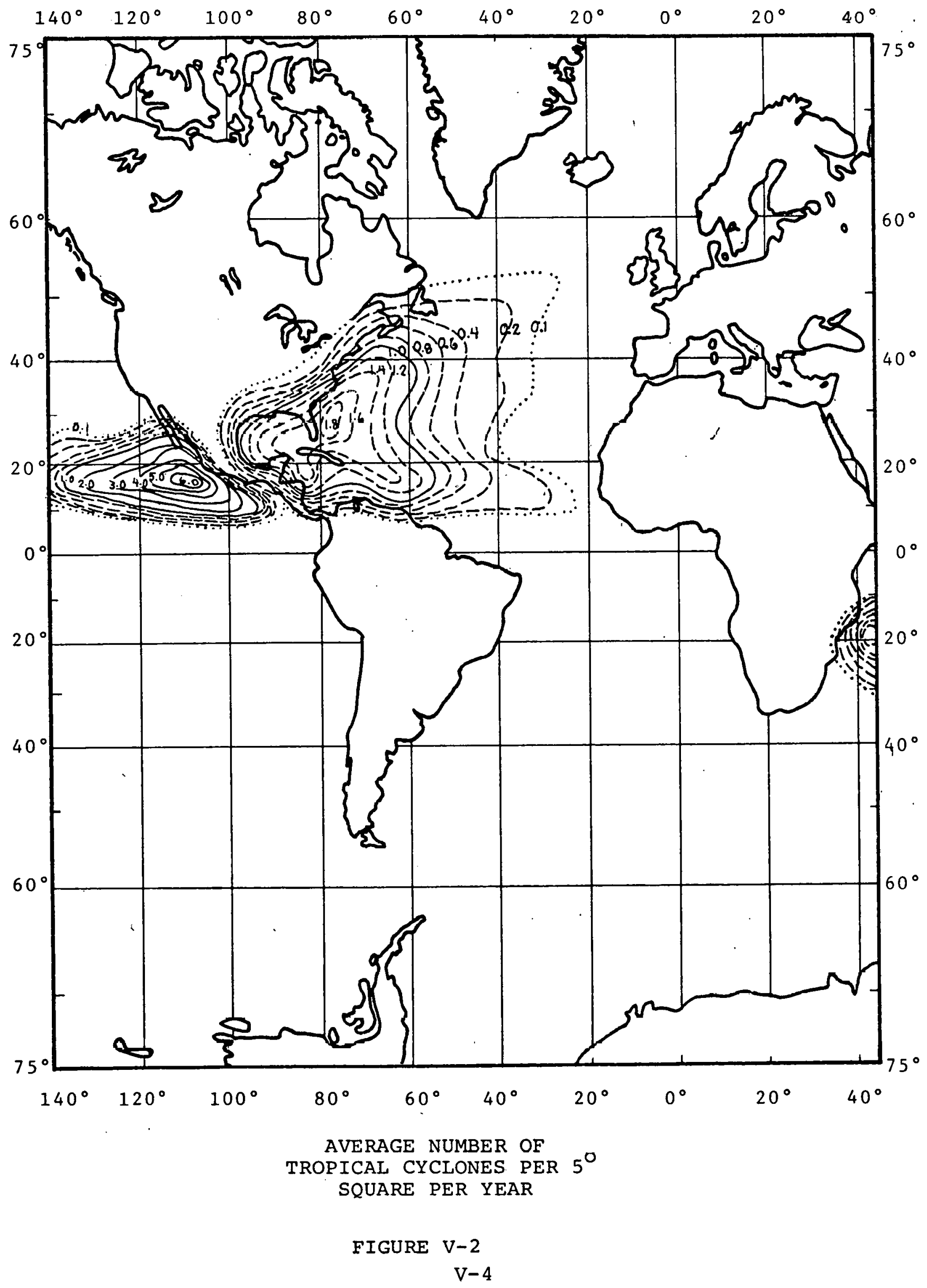


TABLE V-1

RESULTANT WINDS

Average Wind vélocity in Meters per second

\begin{tabular}{|c|c|c|c|c|}
\hline Location & Dec-Jan-Feb & Mar-Apr-May & Jun-Jul-Aug & Sep-Oct-Nov \\
\hline Ivory Coast & $3.1-4.1$ & $3.1-4.1$ & $4.1-5.1$ & $4.1-5.1$ \\
\hline Mombasa & $5.1-6.2$ & $4.1-5.1$ & $6.2-7.2$ & $.4 .1-5.1$ \\
\hline Sri Lanka & $\begin{array}{l}4.1-5.1 W \\
5.1-6.2 E\end{array}$ & $4.1-5.1$ & $\begin{array}{l}6.2-7.2 W \\
7.2-8.2 E\end{array}$ & $5.1-6.2$ \\
\hline Jakarta & 4.1 & $3.1-4.1$ & $5 . i-6.2$ & $5.1-6.2$ \\
\hline Dampier Land & $4.1-5.1$ & $4.1-6.2$ & $5.1-6.2$ & $4.1-5.1$ \\
\hline Philippines & $5.1-6.2$ & $3.1-4.1$ & 4.1 & $6.2-7.2$ \\
\hline Guam & $5.1-6.2$ & $4.1-5.1$ & $4.1-5.1$ & $4.1-5.1$ \\
\hline Off Mexico & $3.1-4.1$ & $2.1-4.1$ & $2.1-4.1$ & $4.1-5.1$ \\
\hline $\begin{array}{l}\text { Plant Ship } \\
\text { Pacific }\end{array}$ & $3.1 \div 4.1$ & $3 \cdot 1-4 \cdot 1$ & $4.1-5.1$ & $4.1-6.2$ \\
\hline $\begin{array}{l}\text { Plant Ship } \\
\text { Caribbean }\end{array}$ & $6.2-7.2$ & $5.1-6.2$ & $6.2-8.2$ & $4.1-5.1$ \\
\hline
\end{tabular}


TABLE V-2

FREQUENCY AND PERCENTAGE OF MODERATE GALES AND STRONGER WINDS,

.BEAUFORT FORCE 7 AND HIGHER

( $\geq 14.4$ meters per second)

\begin{tabular}{|c|c|c|c|c|c|c|c|c|c|c|}
\hline MCHTH & $\begin{array}{l}\text { IVORY } \\
\text { CCAST }\end{array}$ & NOMBASA & $\begin{array}{c}\text { SRI } \\
\text { LéANKA }\end{array}$ & JAKARTA & $\begin{array}{c}\text { DAMP IER } \\
\text { LAND }\end{array}$ & PHILLIPINES & GUAM & $\begin{array}{c}\text { OFF } \\
\text { MEXICO }\end{array}$ & \begin{tabular}{|c|} 
PLANT \\
SHIP \\
(PACIFIC) \\
\end{tabular} & $\begin{array}{c}\text { PLANIT } \\
\text { SHIP } \\
\text { (CARIBN) } \\
\end{array}$ \\
\hline JAN & 0 * & $0-1$ & 0 & 0 & 0 & $1-5$ & $1-5$ & $1-5$ & 0 & 5 \\
\hline FEB & 0 & 0 & 1 & $1-5$ & $1-5$ & 5 & $1-2$ & $1-2$ & 0 & 5 \\
\hline MAR & $1-2$ & 0 & 0 & $1-2$ & $1-2$ & 1 & 0 & $1-2$ & 0 & $1-5$ \\
\hline$I \mathrm{PR}$ & 0 & 0 & 0 & $1-2$ & 0 & 1 & $1-5$ & 1 & 0 & $1-5$ \\
\hline I.IAY & 0 & 1 & $1-5$ & 1 & 0 & $1-5$ & 0 & 0 & 0 & 1 \\
\hline JUN & 0 & $5-10$ & $5-10$ & $1-5$ & 0 & $1-5$ & 0 & 1 & 0 & $1-5$ \\
\hline JUL & 0 & $\begin{array}{r}5-10 \mathrm{~N} \\
10-20 \mathrm{~S}\end{array}$ & $1-5$ & $1-5$ & $1-5$ & 5 & 0 & 0 & 0 & $1-5$ \\
\hline AUG & 0 & $\begin{array}{l}1-5 S \\
5-15 \mathrm{~N}\end{array}$ & $1-5$ & 0 & 0 & $1-5$ & $1-5$ & $1-5$ & 0 & $1-5$ \\
\hline SEF & 0 & 0 & $1-5$ & $1-5$ & 0 & 5 & $1-5$ & 0 & 0 & 1 \\
\hline OCT & 0 & 0 & $\begin{array}{c}\text { OW } \\
1-5 E\end{array}$ & $1-5$ & 0 & $1-5$ & $1-2$ & 1 & 1 & $1-5$ \\
\hline NOV & 0 & 0 & $1-5$ & $1-5$ & 0 & $\begin{array}{r}10-15 N \\
1-10 S\end{array}$ & $5-15$ & $1-5$ & $0-5$ & $1-5$ \\
\hline DEC & 0 & $1-2$ & $\begin{array}{c}0 W \\
1-5 E\end{array}$ & $1-5$ & 0 & $\begin{array}{r}10-15 N \\
5-10 S\end{array}$ & $1-5$ & $1-5$ & 0 & $1-5$ \\
\hline
\end{tabular}

* $0=$ fer or none. 
TABLE $V \dot{-3}$

PERCENTAGE OF WINDS WITH BEAUFORT FORCE 8 AND HIGHER

( $\geq 17.5$ meters per second)

\begin{tabular}{|c|c|c|c|c|c|}
\hline LOCATION & \multicolumn{2}{|c|}{ Dec-Jan-Feb } & Mar-Apr-May & Jun-Jul-Aug & Sep-Oct-Nov \\
\hline Ivory Coast & & 0 & 1 & 0 & 0 \\
\hline Nombasa & $\begin{array}{l}\mathrm{N} \\
\mathrm{S}\end{array}$ & $\begin{array}{l}1 \\
0\end{array}$ & 0 &, 0 & 0 \\
\hline Sri Lanka & & 0 & 0 & 1 & 0 \\
\hline Jakarta & ' & 1 & 1 & 0 & 1 \\
\hline Dampier Land & & 1 & 1 & 0 & 0 \\
\hline Philippines & & 5 & 0 & 1 & $1-5$ \\
\hline Guam & & 0 & 1 & 1 & $1-5$ \\
\hline Off Mexico & & 1 & 1. & 0 & $i$ \\
\hline $\begin{array}{l}\text { Plant Ship } \\
\text { Pacific }\end{array}$ & & 0 & 1 & 0 & 0 \\
\hline $\begin{array}{l}\text { Plant Ship } \\
\text { Caribbean }\end{array}$ & & 1 & 0 & 1 & 0 \\
\hline
\end{tabular}


TABLE V-4

PREDOMINANT SURFACE WIND DIRECTION

\begin{tabular}{|c|c|c|c|c|c|c|c|c|c|c|}
\hline MONTH & MOMBASA & $\begin{array}{l}\text { SRI } \\
\text { LANKA }\end{array}$ & $\begin{array}{c}\text { DAMPIER } \\
\text { LAND }\end{array}$ & JAKARTA & MANILA & GUAM & MEXF & $\begin{array}{l}\text { PLAANT } \\
\text { SHIP } \\
\text { (PACIFIC) }\end{array}$ & $\begin{array}{l}\text { PLANT } \\
\text { SHIP } \\
\text { (CARIBN) }\end{array}$ & $\begin{array}{l}\text { IVORY } \\
\text { COAST }\end{array}$ \\
\hline JAN & $\downarrow$ & $\swarrow$ & $\nearrow \nearrow$ & $\searrow$ & $\downarrow$ & $\swarrow$ & $\searrow$ & $\swarrow$ & $\swarrow$ & $\uparrow \nearrow$ \\
\hline FEB & $\downarrow$ & $\swarrow$ & $\lambda$ & $\rightarrow$ & $\swarrow$ & $\swarrow$ & $\downarrow$ & $\swarrow$ & $\measuredangle$ & $\uparrow$ \\
\hline MAR & $<$ & $\downarrow \circ \xi$ & 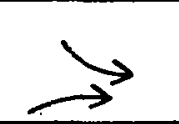 & $\longrightarrow$ & $\downarrow$ & $\downarrow$ & $\searrow$ & $\swarrow$ & $\leftarrow$ & $\uparrow$ \\
\hline APR & $0^{\circ} \frac{\swarrow}{\Omega}$ & $\rho_{y}^{\prime}$ & $k$ & $R$ & $\downarrow$ & $<$ & $\searrow$ & $\swarrow$ & $\leftarrow$ & $\uparrow$ \\
\hline MAY & $\uparrow \uparrow$ & $\pi$ & $\pi$ & $R$ &. & $\swarrow$ & $\searrow$ & $\pi$ & $\leftarrow$ & $\uparrow$ \\
\hline JUN & $\uparrow$ & $\pi$ & $\pi$ & $\nwarrow$ & $\nearrow$ & $\leftarrow$ & $\nabla$ & $y_{i} k$ & $\leftarrow$ & $\uparrow$ \\
\hline JUL & $\uparrow$ & $\lambda$ & $\pi$ & $\pi$ & $\pi$ & $\uparrow$ & $\Delta$ & $\uparrow$ & $\leftarrow$ & $\uparrow$ \\
\hline AUG & $\uparrow$ & $\pi$ & $\nwarrow$ & $\pi$ & $\nearrow$ & $\leftarrow$ & $\downarrow$ & $\vec{\uparrow} \overrightarrow{ }$ & $\leftarrow$ & $\nearrow$ \\
\hline SEP & $\uparrow$ & $\rightarrow 0^{\lambda}$ & $\pi$ & $\pi$ & $r_{\lambda}$ & $\leftarrow$ & $\searrow$ & $\nearrow$ & $\leftarrow$ & $\uparrow$ \\
\hline OCT & $\uparrow$ & $\rightarrow$ & $\kappa$ & $\kappa$ & $\swarrow$ & $\swarrow$ & $\downarrow$ & $\uparrow$ & $\leftarrow$ & $\uparrow$ \\
\hline Nov & $\frac{K}{s}$ & $\rightarrow$ & 9 & $\bar{r}$ & $\swarrow$ & $\downarrow$ & $\downarrow$ & $\begin{array}{ll}k \downarrow \\
1 & \end{array}$ & $\leftarrow$ & $\uparrow$ \\
\hline $\mathrm{DEC}$ & $\swarrow$ & $\swarrow$ & $\nearrow$ & $r$ & $\downarrow$ & $\swarrow$ & $\downarrow$ & $\leftarrow$ & $\ll$ & $\nearrow$ \\
\hline
\end{tabular}




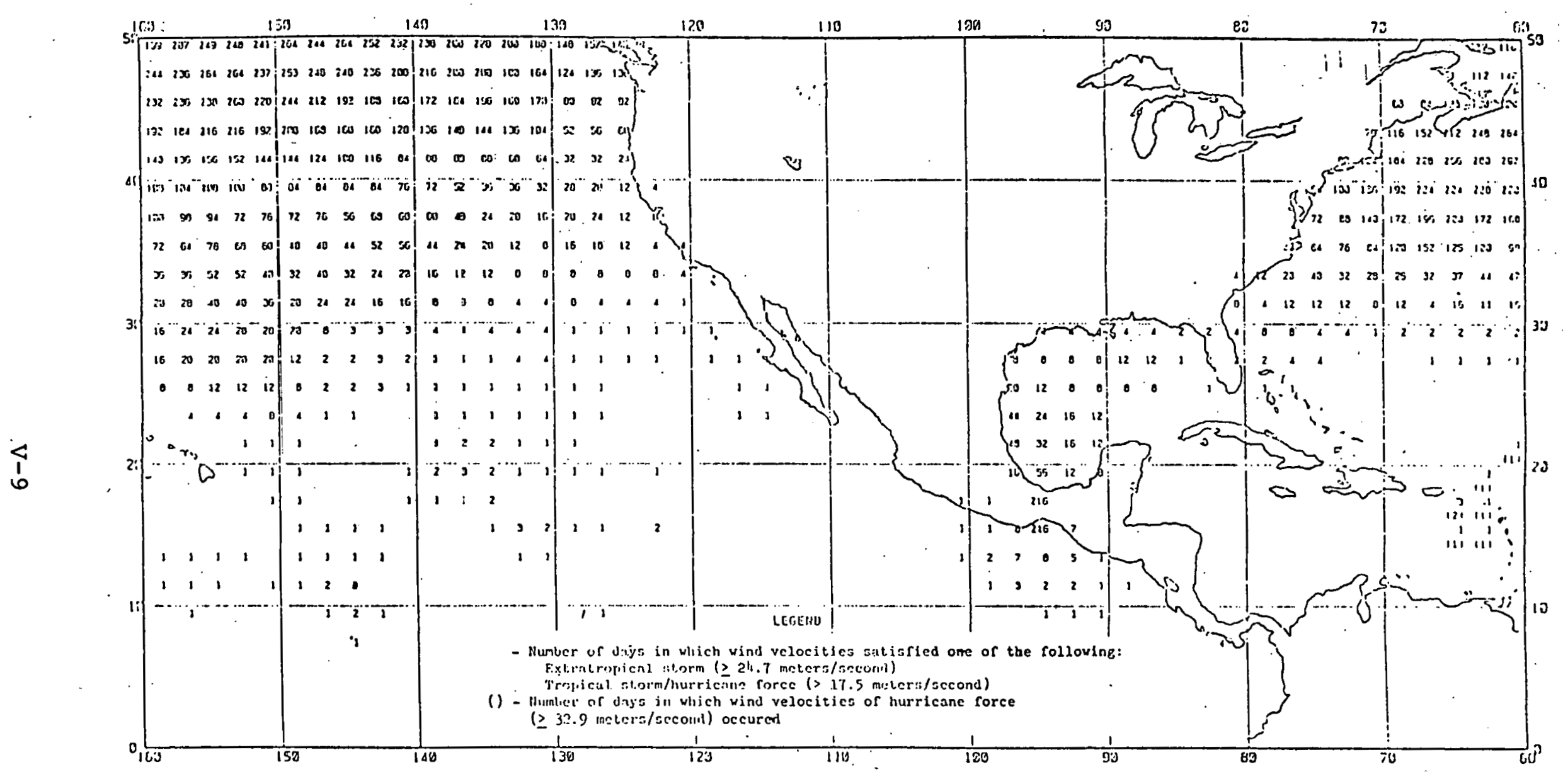

FIGURE V-3: STORM/HURRICANE STATISTICS - DECEMBER, JANUARY, FEBRUARY 


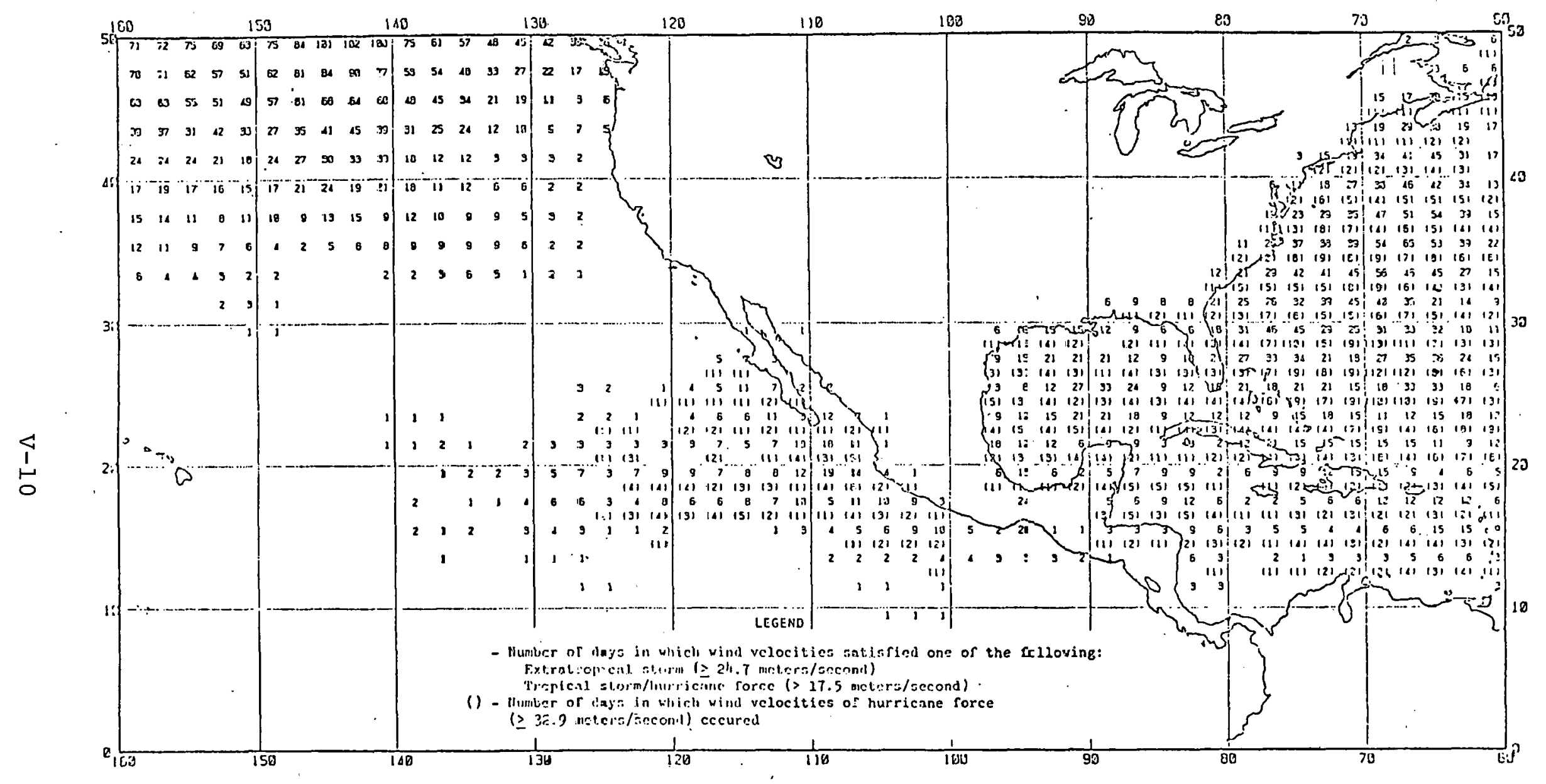

FIGURE V-4: S'TORM/HUZRICANE STATISTICS - SEPTEMBER, OCTOBER, NOVEMBER 


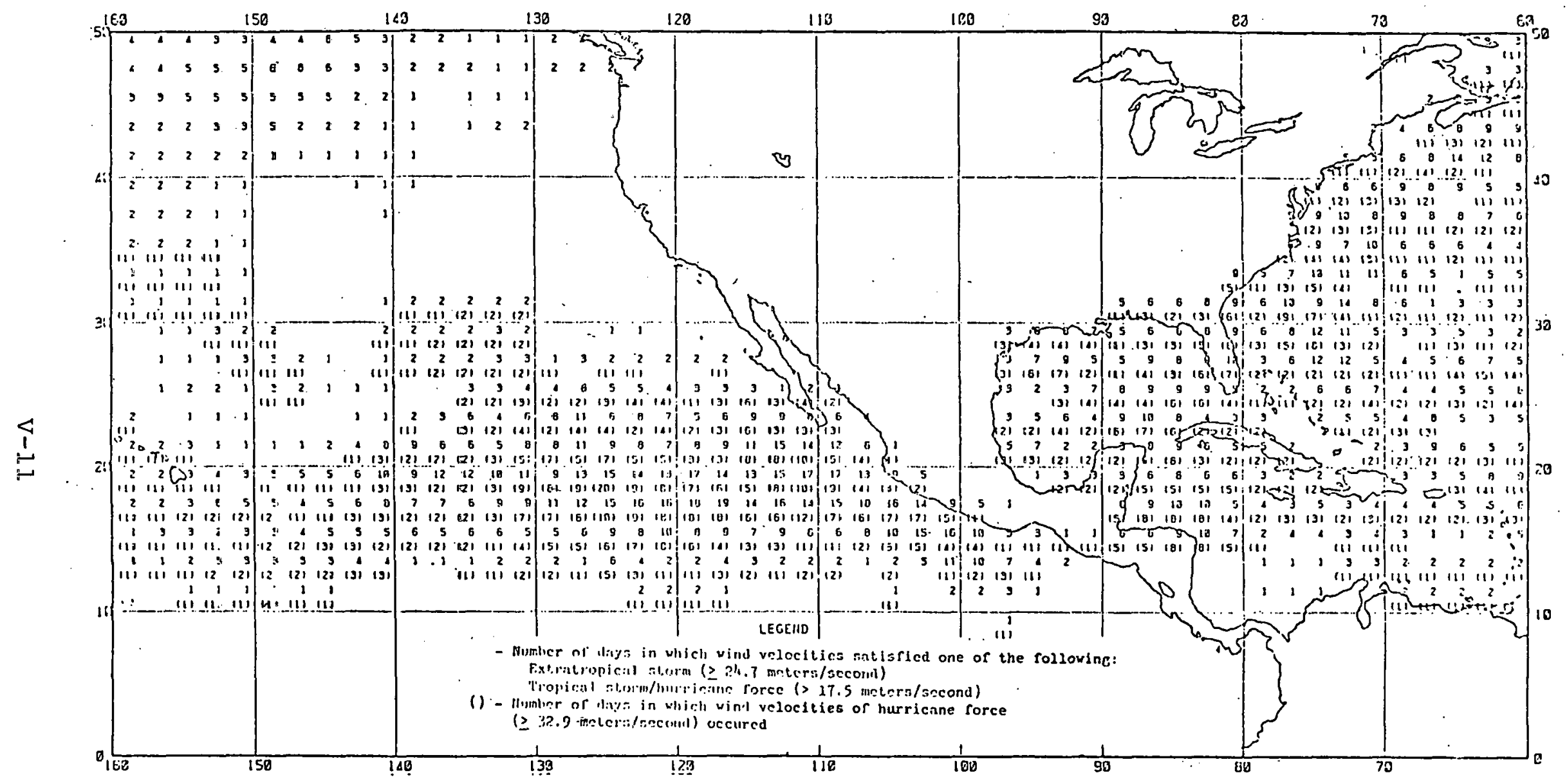

FIGURE V-5: STORM/HURRICANE STATISTICS - JUNE, JULY, AUGUST 


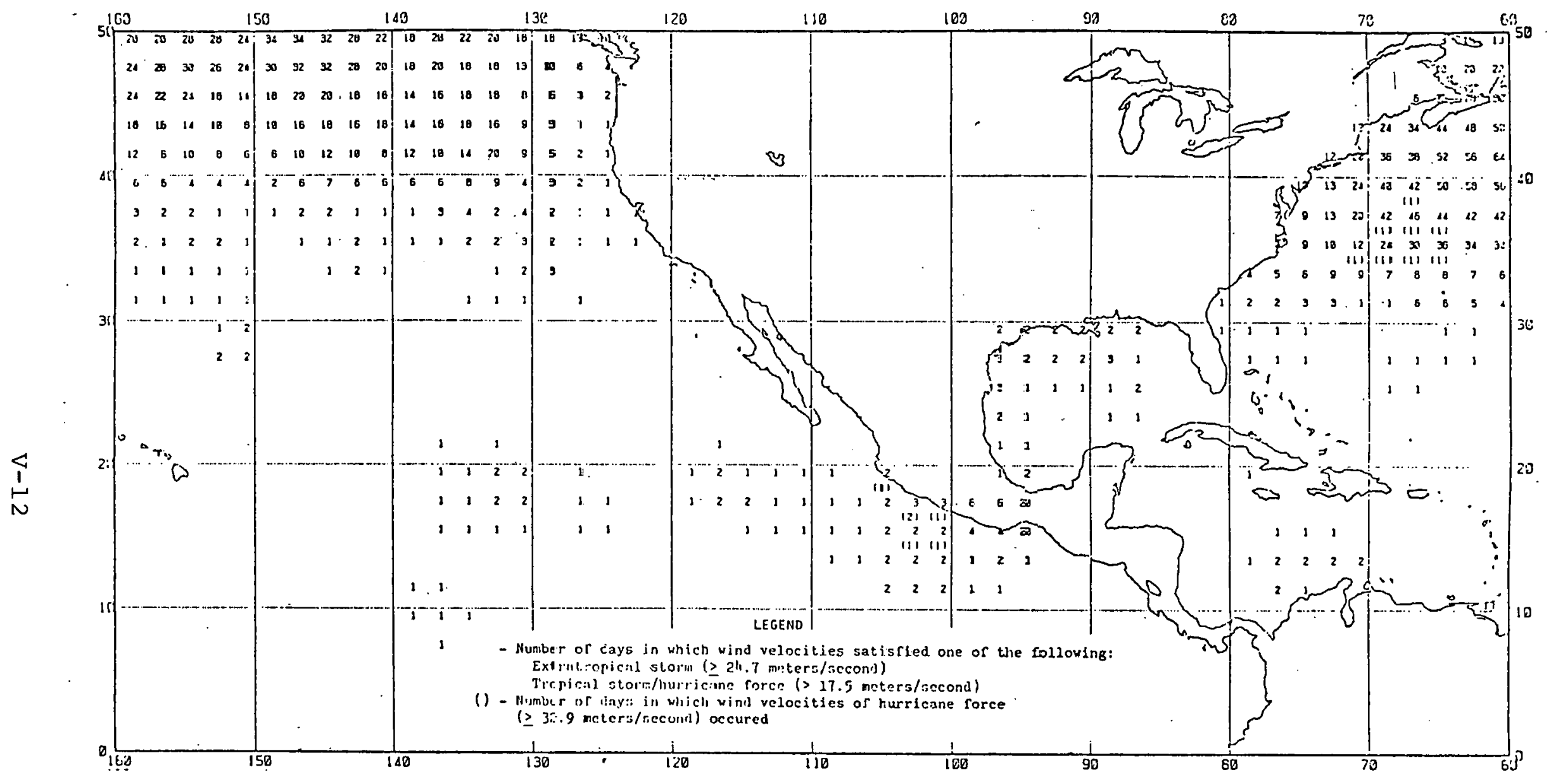

FIGURE V-6: STORM/HURRICANE STATISTICS - MARCH, APRIL, MAY 
Low sea and swell conditions predominate throughout the year for the off Mexico site. For each of the four seasons the wave height of 2.4 meters or more exists two percent of the time or less.

Monthly sea and swell data for this site was taken from the U.S. Hydrographic Office, (1964), [34]. For January the predominant direction of the sea and swell was from the north and the northwest. Six percent of the sea observations and nineteen percent of the swell observations were calm. Less than five percent of either the sea or swell observations were high. For March the predominant direction of the sea and swell was from the northwest, with less than two percent of the observations being high. For June the predominant direction of the sea and swell was again from the northwest, although a significant portion was from the west. Only one percent of the observations were high, that is with force 5 or greater. For August the predominant direction of the observations was from the northwest, although there were significant observations from the west, south and southwest. The percontage of low sea aind swells was between 70 to $80 \%$ from each direction. For October through December the predominant direction of sea and swell was from the northwest, and particularly from the latter two months also from the north. The percentage of high sea and swell was less than $2 \%$ of the total number of observations. 
VII. CURRENTS

This off Mexico site is not located near one of .

prominent surface current systems in the North Pacific. The area is. south of the California current and north of Pacific North Equatorial Current. Figures VII-1 through VII-4

present the ocean surface current patterns from Defense Mapping Agency Hydrographic Center Pilot Charts (1975) for the months of January, April, July and October. Monthly mean surface currents from 1978 Pilot Charts in cm/sec are as follows:

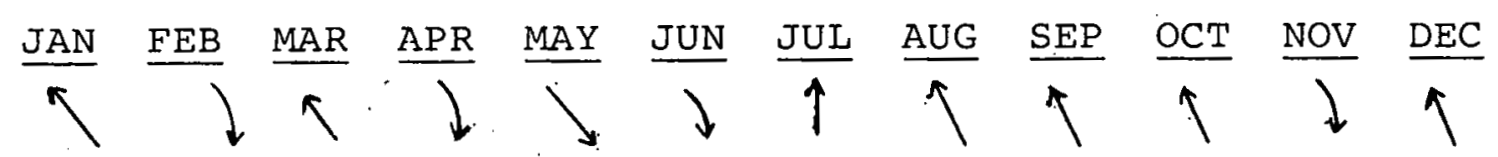
$\begin{array}{llllllllllllll}25.7 & 25.7 & 30.8 & 25.7 & 25.7 & 25.7 & 25.7 & 25.7 & 25.7 & 25.7 & 25.7 & 30.8\end{array}$

Current directions are shown by arrows and current speeds are given in $\mathrm{cm} / \mathrm{sec}$. The currents in this area are weak and variable in direction. This basic current information is derived from Pilot Charts which are based on ship logs. These records of a ships position are interpreted in terms of the set and drift of current between fixes of the ships position. Few direct measurements of currents are available, and very Lew sub-surface measurements.

These current figures are mean, useful as a rough estimate, but not indicators of currents where high wind or sea and swell conditions exist. Hurricanes also effect surface current conditions. Leipper's (1967, [21] ]) study of Hurricane Hilda showed that a current had developed in the 


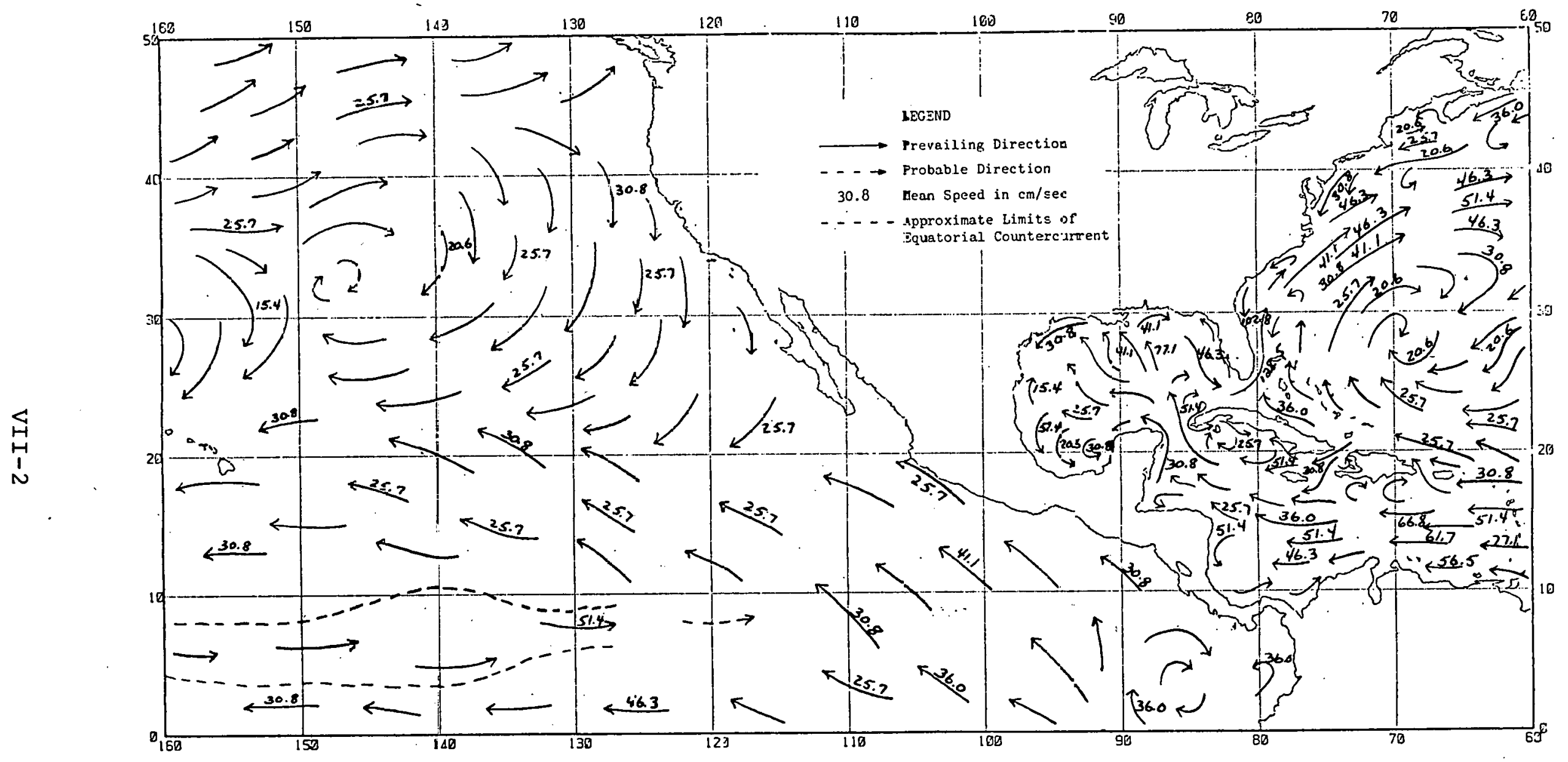

IIGURE VII-1: MEAN SURFACE CURRENT CHART - JANUARY. 


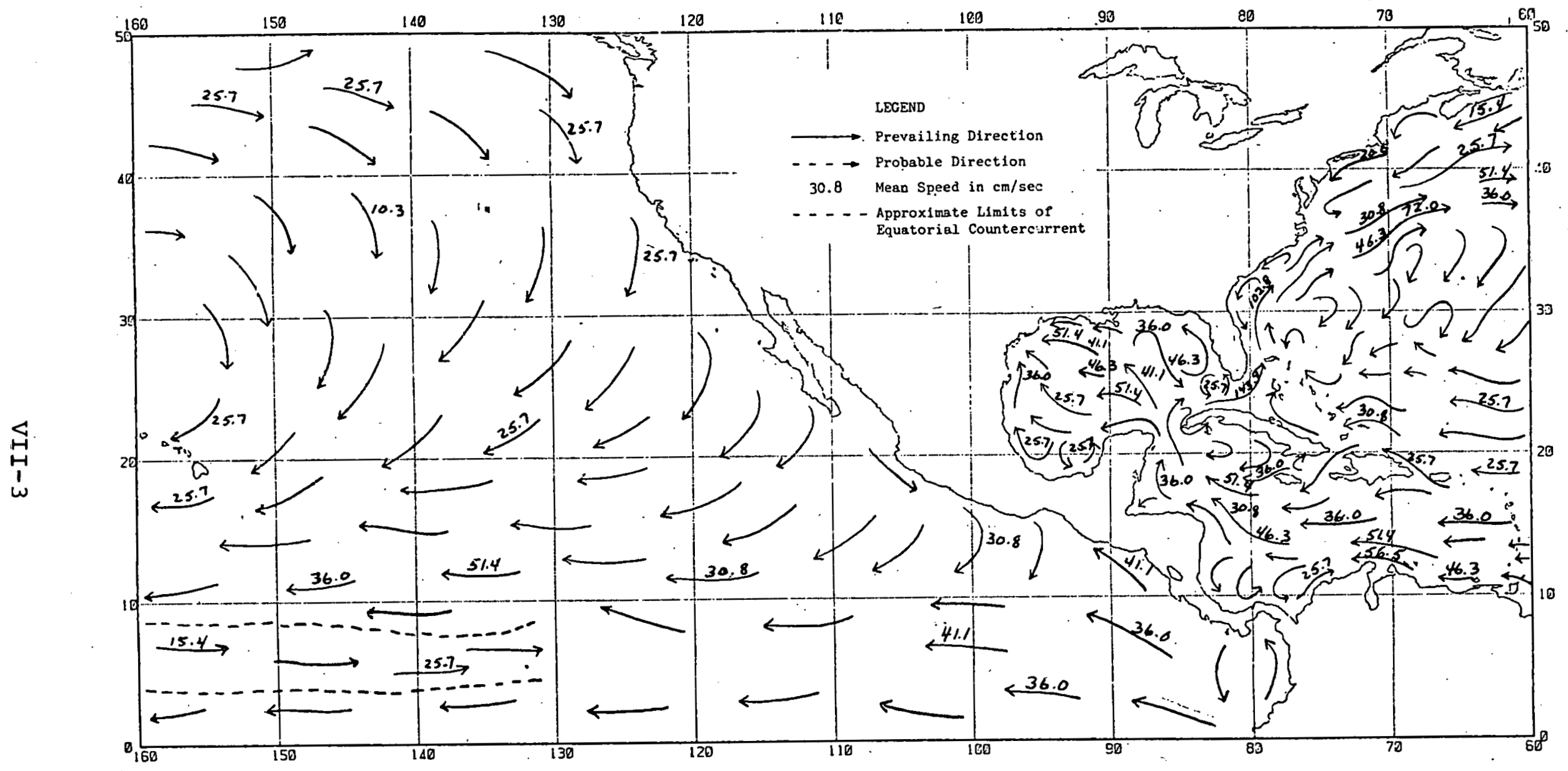

FIGURE VII-2: MEAN SURFACE CURRENT CHART - APRIL. 


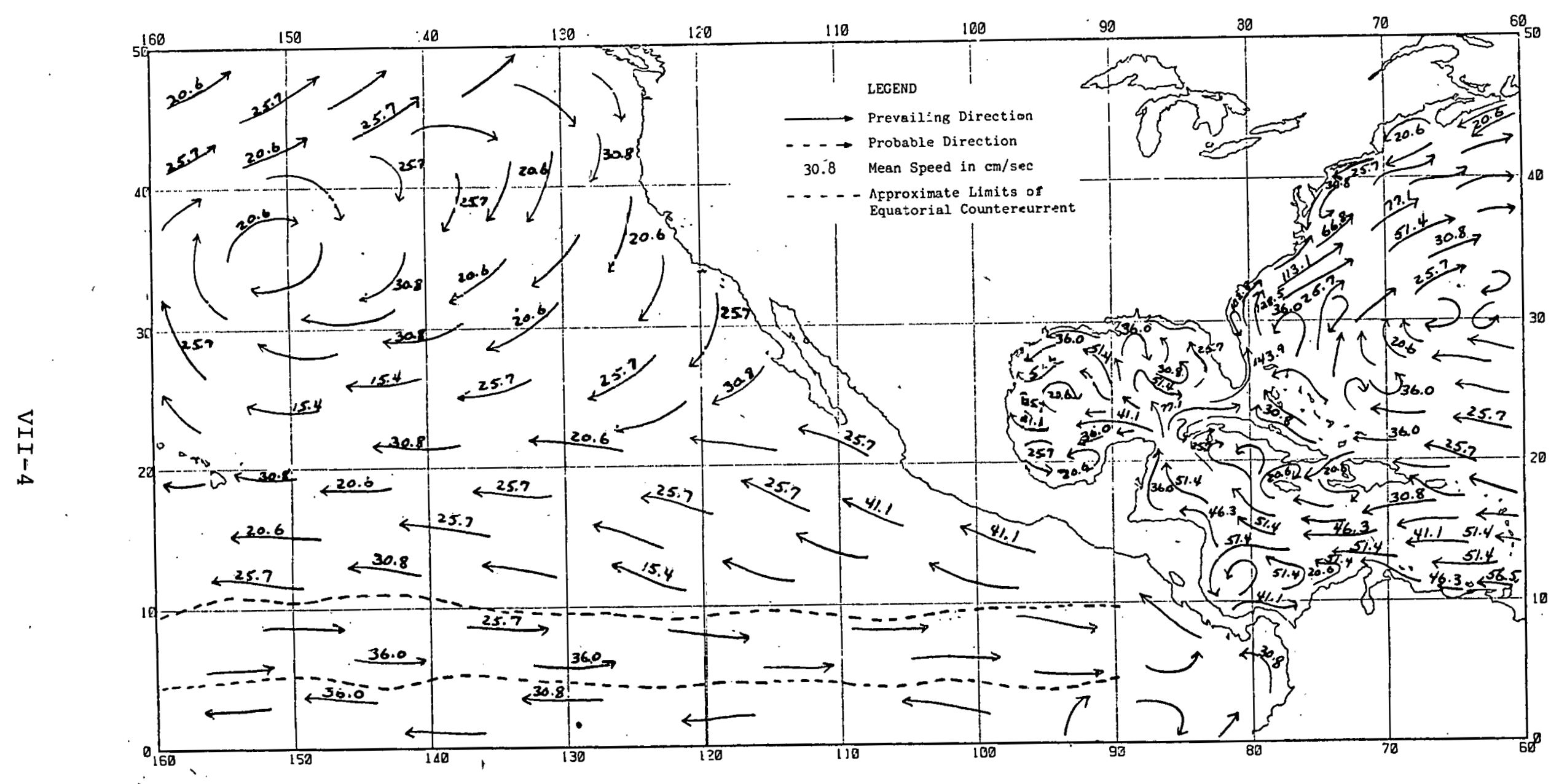

FIGURE VII-3: MEAN SURFACE CURRENT CHART - JULY. 


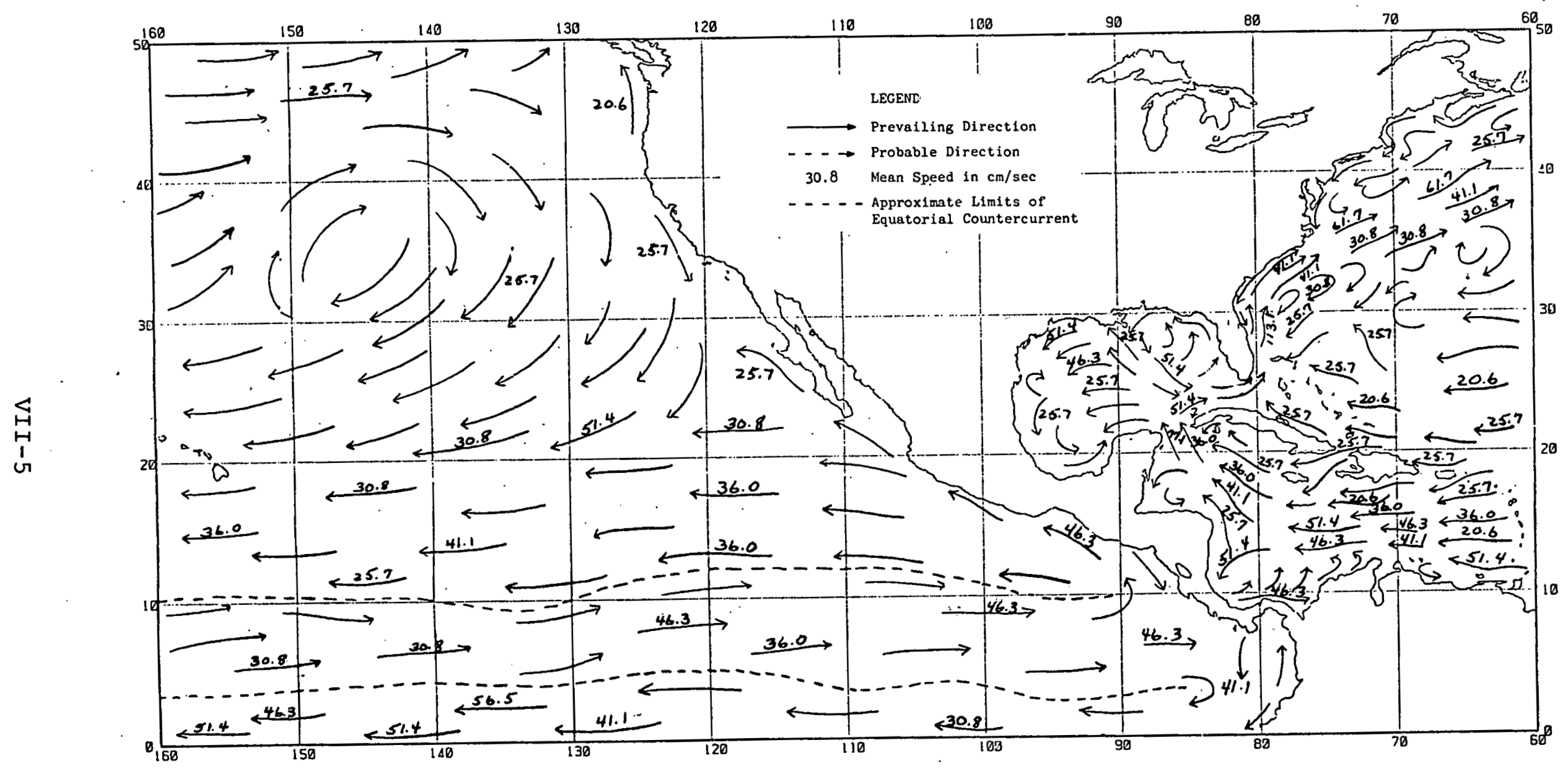

FIGURE VII-4: MEAN SURFACE CURRENT CHART - OCTOBER 
area transversed by the storm. Analysis of temperaturedepth data showed a current of approximately $50 \mathrm{~cm} / \mathrm{sec}$. A theoretical study by O'Brien and Reid (1967, [27]) states that hurricanes will cause currents with a speed of approximately one meter per second.

The passage of hurricanes will induce upwelling of subsurface waters for a temporary period. This upwelling will cause anomalous vertical current shears. Strongest vertical and horizontal current shears are usually associated with major current systems and should not be a problem for this site. 
1. Adamec, D., and O'Brien, J.J., November 1978, "The Seasonal Upwelling in the Gulf of Guinea Due to Remote Forcing", J. Phys. Oceanogr., 8, No. 6, 1050-1060.

2. Atwood, D.K., et al., 1976, Ocean Thermal Energy Conversion, Resource Assessment and Environment Impact for Proposed Puerto Rico Site, University of Puerto Rico.

3. Avery, W.H., et al., 1976, Maritime and Construction Aspects of Ocean Thermal Energy Conversion (OTEC) Plant Ships, The John Hopkins University Applied Physics Laboratory, Laurel, Maryland.

4. Bathen, K.H., et al., 1977, "Consolidated Oceanographic and Meteorological Data for Four North Pacific OTEC Sites", University of Hawaii.

5. Bigelow, H.B., and W.T. Emundson, 1947, Wind Waves at Sea, U.S. Hydrographic Office, Washington, D.C.

6. Colburn, J.G., 1974, "The Thermal Structure of the Indian Ocean". International Indian Ocean Expedition Oceanographic Monograph No., 2; The University Press of Hawaii; Honolulu, Hawaii.

7. Crutcher, H.L. and R.G. Quayle, 1974, "Mariners Worldwide Climatic Guide to Tropical storms at sea", NAVAIR 50lC-61, Naval Weather Service; Asheville, N.C.

8. Defense Mapping Agency Hydrographic/Topographic Center, 1978, Pilot Chart of the North Pacific, DMA stock Numbers PILOT 557801, 557804, 557810, Washington, D.C.

9. Défense Mapping Agency Hydrographic/Topographic Center, 1978, Pilot Chart of the North Atlantic Ocean, DMA Stock Numbers PILOT 167801, 167804, 167807, 167810, Washington, D.C.

10. Defense Mapping Agency Hydrographic Center, South Pacific Ocean, Sheet IV, Pub. N.O. 623, revised 1974, Washington, D.C.

11. Defense Mapping Agency Hydrographic Center, Indian Ocean, Northern Part, Pub No. 721, 1974, Washington, D.C..

12. Defense Mapping Agency Hydrographic. Center, Gulf of Mexico and Carribean Sea, Pub. No. 410, revised 1973, Washington, D.C.

$$
\mathrm{R}-1
$$


13. Defense Mapping Agency Hydrographic Center, North Atlantic Ocean, Southeastern Sheet, Publication N.O. 125, 4th ed., 1974, Washington, D.C.

14. Düing, W., 1970; "The Monsoon Regime of the Currents in the Indian Ocean", International Indian Ocean Expedition Oceanographic Monograph No. 1, Hawaii Institute of Geophysics Contribution No. 331, the University of Hawaii Press; Honolulu, Hawaii.

15. Düing, W. and F. Schott; March 1978, "Measurements in the Source Region of the Somali Current during the Monsoon Reversal", J. Phys. Oceanogr., 8, 278-289.

16. Emilsson, J., 1970, "On the Upper Layer Circulation in the Cayman Sea", from the Symposium on the Investigations and Resources of the Caribbean Sea and Adjacent Regions, UNESCO, Paris France.

17. Fleet Numerical Weather Central.(FNWC), FNWC and National Oceanographic Data Center digitized reports.

18. Gentry, R.C., 1970, "Hurricanes, One of the Major Features of Air-Sea Interaction in the Caribbean sea"', from the Symposium on the Investigation and Resources of the Caribbean Sea and Adjacent Regions, UNESCO, Paris, France.

19. Hogben, N., and F. Lumb, 1967, Ocean Wave Statistics, National Physical Laboratory, Ministry of Technology, London. Her Majesty's Stationery Office.

20. Johnson, A. and S. Denwick, 1978; "Data Report Buoy Observations During Hurricanes Anita and Babe, August-, September, 1977", NOAA Data Buoy Office, National space Technology Laboratories, NSTL Station; Mississippi..

21. Leipper, D.F., 1967, "Observed Ocean Conditions and Furricane Hilda, 1964. J. Atmos Sci., 24, p 182-196.

22. McFadden J.D., "Airborne Investigations of the Effects of Hurricanes on the Thermal structure of the surface Layer of the Ocean", from the Symposium on Investigation and Resources of the Caribbean Sea and Adjacent Regions, UNESCO, Paris France.

23. National Oceanographic Data Canter, The Varinhility of Water Masses in the Indian Ocean, Publication G-11, Washington, D.C. 
24. National Oceanographic Data Center, Data File BTG75A, Washington, D.C., 1977.

25. National Oceanographic Data Center, Data Files SD40A5/0A6 from SD76A (1/30/76) 3509 STA: Washington, D.C., 1977.

26. National Science Foundation, 1972, Meteorological Atlas of the International Indian Ocean Expedition, Volume 7 , Washington, D.C.

27. O'Brien, J.J., and R.O. Reid, 1967, "The Non-Linear Response of a Two Layer Baroclinic Ocean to a Stationery Axially Symetric Hurricane", J. Atmos. Sci., 24, p 197215 .

28. Ramage, C.D., 1972, "Indian Ocean Surface Meteorology", International Indian Ocean Expedition, Collective Reprints VIII, Contribution No. 624, pgs 407-540; Paris, France.

29. Sirvastava, P.S., P.K. Vyayarayou and M.X. Joseph, 1972 "Monthly Wave Characteristics of the Bay of Bengal", International Indian Ocean Expedition, Collective Reprints VIII, Contribution No. 625, Paris, France.

30. The Enclyopedia of Oceanography, 1966, Reinhold Publishing Corp., New York, New York.

31. U.S. Department of Agriculture, Weather Bureau, 1938, "Atlas of Climatic Charts of the Oceans", Washington, D.C.

32. U.S. Department of Commerce, NOAA, 1971, Eastropac Atlas, Volume 3, Washington, D.C.

33. U.S. Navy, 1975, Marine Climatic Atlas of the World, Volume III, Indian Ocean, Washington, D.C.

34. U.S. Navy Hydrographic Office, 1964, Atlas of Sea and Swell Charts, Northeastern Pacific Ocean, Publication No. 799n, revised 1976, Washington, D.C.

35. U.S. Naval Weather Service, September 1974, Climatic Summaries For Major Indian Ocean Ports and Waters, NAVAIR 50-1C-63, Asheville, N.C.

36. U.S. Naval Weather Service, November 1973, Climatic Summaries For Major Seventh Fleet Ports and Waters, NAVAIR 50-lC-62, Asheville, N.C.

37. U.S. Naval Oceanographic Office, 1963, Oceanographic Atlas of the North Atlantic Ocean, Washington, D.C. 
38. U.S. Naval Oceanographic Office, Bathymetric Atlas of the Northeastern Pacific Ocean, Pub No. 1303-S, No. $0902 \mathrm{~N}, 0903 \mathrm{~N}, 1002 \mathrm{~N}, 1003 \mathrm{~N}$, Washington, D.C.

39. U.S. Naval Oceanographic Office, Indian Ocean, AfricaEast Coast Publication No. 724, lst ed., 1974, Washington, D.C.

40. U.S. Naval Oceanographic Office, 1971, Eathymetric Atlas of the Northeastern Pacific Ocean, H.O. Pub No. $1303-\mathrm{S}$, N.O. $1104 \mathrm{~N}, 1105 \mathrm{~N}, 1204 \mathrm{~N}, 1204 \mathrm{~N}$, Washington, D.C.

41. U.S. Naval Oceanographic Office, 1971, Bathymetric Atlas of the Northeastern Pacific Ocean, H.O. Pub N.O. $1301-S, 2403 \mathrm{~N}, 2040 \mathrm{~N}$, Washington, D.C.

42. U.S. Naval Uceanographic officie, 1970, Bathymetric Atlas of the Northwestern Pacific Ocean, H.O. Pub. 1201-S, N.U. 2203N, Washingtun, D.C.

43. Wolff, P.M. and W.E. Hubert, 1976, "Ocean Thermal Energy Conversion: Resource, Ecological and Environmental Studies", Contract No. NSF-C1020, Ocean Data Systems, Inc., Monterey, California.

44. Wolff, P.M., et al, 1977, "OTEC Resource Report for Hawail", Contract EG-77-C-01-4028, Ocean Data Systems, Inc., Monterey, California.

45. Wyrtki, K., 1972, "The Upwelling in the Region Between Java and Australia during the South-East Monsoon, Collected reprints of the International Indian Ocean Expedition, Volume I, Contribution No. 15, pp 151-161.

46. Wyrtki, K., 1972, "Geopotential Topographics and Associated Circulation in the South Eastern Indian Ocean", Collected reprints of the International Indian Ocean Expedition, Volume $I$, contribution No. 14 .

47. Wyrtki, K., 1971, Oceanographic Atlas of the International Ocean Expedition, National Science Foundation, NSF-IOE1, Washington, D.C. 